\title{
LA CRÍTICA AL DESPOTISMO DE LAS DINASTÍAS EXTRANJERAS (AUSTRIAS Y BORBONES): LOS DIPUTADOS CATALANES Y LAS CORTES DE CÁDIZ
}

\section{THE CRITICISM TO THE DESPOTISM OF THE FOREIGN DYNASTIES (HABSBURG AND BOURBON). THE CATALAN DEPUTIES AND THE SPANISH PARLIAMENT OF CADIZ}

\author{
Antoni Sánchez Carcelén \\ Universidad de Lleida
}

\begin{abstract}
SUMARIO: I.- EL ELOGIO AL LEGADO CONSTITUCIONAL MEDIEVAL. II.- LA CRÍTICA A LA DERIVA DESPÓTICA DE LOS AUSTRIAS. III.- LA CRÍTICA AL ABSOLUTISMO DE LOS BORBONES. IV.- CONSIDERACIONES FINALES
\end{abstract}

Resumen: Haciendo uso del recurso historicista los diputados catalanes que asistieron a las Cortes de Cádiz reivindicaron el modelo político pactista propio de la antigua Corona de Aragón con el objetivo de hallar un antecedente autóctono que pudiera legitimar el proceso constituyente doceañista. Máxime, cuando los parlamentarios catalanes consideraron que a partir de la entronización de las dinastias extranjeras (Austrias y Borbones) se impuso como forma de gobierno el despotismo regio y ministerial.

Abstract: Making use of the historicist resource the Catalan deputies who attended the Spanish Parliament of Cadiz claimed the political model of pacts of the old Crown of Aragon with the aim of finding an autochthonous antecedent that could legitimize the liberal constituent process. Especially, when they considered that from the enthronement of the foreign dynasties (Habsburg and Bourbon) was imposed like form of government the royal and ministerial despotism.

Palabras clave: Cortes de Cádiz, diputados catalanes, despotismo, Austrias y Borbones.

Key words: Spanish Parliament of Cadiz, Catalan deputies, despotism, Habsburg and Bourbon.

\section{I.- EL ELOGIO AL LEGADO CONSTITUCIONAL MEDIEVAL}

La invasión napoleónica evidenció la quiebra de la monarquía absoluta borbónica $\mathrm{y}$, por ende, de las instituciones tradicionales representativas del Antiguo Régimen. Con el objetivo de suplir el desconcertante vacío de poder se erigieron unas revolucionarias juntas provinciales y corregimentales destinadas a organizar la resistencia patriótica. Mediante la formación de la Junta Central en Aranjuez el 25 de septiembre de 1808 se unificó la acción gobernativa. Precisamente, la Junta Suprema gubernativa del Reino promulgó un decreto el 22 de mayo de 1809 dictaminando la convocatoria de Cortes a partir de la 
constatación que "los desastres que la nación padece han nacido únicamente de haber caído en el olvido aquellas saludables instituciones que en tiempos más felices hicieron la prosperidad y la fuerza del Estado". ${ }^{1}$ He aquí el punto de partida de un relato que será recurrente en el Congreso gaditano ${ }^{2}$ que pretendía hacer creer que no se trataba de innovar o copiar nada, sino únicamente de redescubrir unos principios politicos que habían sido olvidados durante la Edad Moderna a partir del reinado de las dinastías extranjeras, y cuyo abandono había supuesto una inexorable decadencia.

Ante la necesidad de coordinar las tareas preparatorias la Junta Central organizó una Comisión de Cortes asistida a su vez por una serie de organismos auxiliares. La dedicada a establecer el adecuado ceremonial de Cortes estuvo presidida por Antonio de Capmany y Montpalau, quién, en calidad de erudito filólogo, archivero e historiador, fue el encargado "de recoger cuantas memorias históricas pudiese hallar acerca de las antiguas Cortes de Castilla, Aragón, Cataluña, Valencia y Navarra, y de informar cuanto fuese relativo a la reorganización y ceremonial de estos congresos". ${ }^{3}$

A partir de una exhaustiva recopilación documental Antonio de Capmany redactó un Informe sobre la necesidad en que se hallaba la Monarquía de una Constitución. ${ }^{4}$ El principal propósito no era otro que el de hallar en los reinos históricos una tradición constitucional revocada por la paulatina imposición del absolutismo que pudiera legitimar la reciente convocatoria de Cortes. Efectivamente, en primer lugar, el futuro diputado catalán puso de manifiesto que "en nuestros códigos y cuadernos de Cortes, y pragmáticas hecha en ellas, hablan muchas leyes, que el despotismo ha vulnerado o condenado al olvido, porque protegian la libertad de los pueblos y la defensa de sus derechos y franquezas". Eso sí, con la finalidad de evocar una fehaciente constitución histórica únicamente Capmany pudo vindicar las particularidades de la tradición constitucional de la antigua Corona de Aragón y del histórico Reino de Navarra ${ }^{5}$ en oposición a la castellana, ya que, en clave histórica, el archivero halló una gran diferencia entre "la Corona de Castilla [a la que] el poder y representación de

1 Archivo Histórico Nacional, en adelante AHN, Colección de Reales Cédulas, Hacienda, Legajo 4822.

2 En palabras del diputado catalán Felipe Aner "el desprecio y olvido de nuestra Constitución ha conducido a la Nación el estado deplorable en que se halla". Diario de Sesiones de Cortes, en adelante DSC, núm. 472, 18 de enero de 1812, p. 2651.

3 En el Archivo del Congreso de los Diputados, en adelante ACD, Legajo 3, núm. 5, se halla la correspondencia que mantuvo Antonio de Capmany con la comisión auxiliar del ceremonial de Cortes.

4 En la Biblioteca Nacional, en adelante BN, existe una copia del Informe presentado a la Comisión de Cortes sobre la necesidad en que se hallaba la Monarquia de una Constitución, Sevilla, 17 de octubre de 1809, Ms. 20260/4. Publicado y comentado por José Álvarez Junco, "Capmany y su Informe sobre la necesidad de una Constitución (1809)", Cuadernos Hispanoamericanos, $\mathrm{n}^{\circ}$ 70, 1967, pp. 520-551.

5 A pesar de que Fernando el Católico llevó a cabo la conquista (1512) y posteriormente incorporación del Reino de Navarra (1515) a la Corona de Castilla, siguiendo la línea tradicional aragonesa, el territorio navarro conservó su consuetudinario derecho y sus privativas instituciones: Consejo Real, Cortes y Diputación del Reino. Al respecto, véase Alfredo Floristán Imizcoz, "¿Conquista o restauración? La incorporación de Navarra a la Monarquía española", Hispania, LIX/2, n 202, 1999, pp. 457-491. 
las Cortes fue débil e incompleto" y la Corona de Aragón, hasta el punto de efectuar una elocuente pregunta retórica: “¿La Corona de Aragón no tuvo por espacio de cinco siglos fueros, constituciones, libertades y franquezas invulnerables, Aragón, Valencia, Cataluña y Navarra no son de España y no lo eran antes?". Más si cabe cuando el literato barcelonés constató que "en las actas de éstas [Cortes de la Corona de Aragón y del Reino de Navarra], que eran tan libremente constituidas, como podía permitirlo una monarquía, se lee y oye la voz de patria, de pueblo, de nación, de constitución, de libertad, nombres que jamás pronunciaron ni las leyes, ni los legisladores en las Cortes castellanas". 6

De esta manera, haciendo uso del recurso historicista, Antonio de Capmany pretendió demostrar que "la proporción general de que España no ha tenida una Constitución legalmente fundada, reconocida y observada para sostener los derechos y la libertad de la nación, es falsa, equivocada y ofensiva a las provincias de fueros que componen una tercera parte de la monarquía". Así pues, según el criterio del historiador catalán, a diferencia de la antigua Corona de Castilla, el régimen constitucional se habia mantenido vigente gracias al sistema político pactista en el Principado de Cataluña y en los Reinos de Aragón, Valencia y Mallorca hasta que dejaron de reinar los Habsburgo, por tanto, "asegurar, como dicen algunos, que jamás ha gozado España de una Constitución que contuviese en sus justos limites la autoridad soberana y las pretensiones de los vasallos, es ignorar nuestra historia, nuestras leyes". No obstante, a diferencia del Reino de Navarra, en la Corona de Aragón la ruptura constitucional tuvo lugar cuando "la Francia nos despojó a principios del siglo pasado [XVIII] de los restos de nuestra antigua libertad". Sin duda, Capmany hizo alusión a la entronización de la dinastía borbónica, a la Guerra de Sucesión (1705-1714) y a los diversos Decretos de Nueva Planta (1707 -Reino de Valencia-, 1711 -Reino de Aragón-, 1715 -Reino de Mallorca- y 1716 -Principado de Cataluña-) destinados a derogar los privilegios, constituciones, fueros e instituciones de los territorios de la antigua Corona de Aragón. De hecho, de acuerdo al Informe elaborado por Capmany el papel de las diversas Cortes de la Corona de Aragón como eficaz contrapoder capaz de limitar el poder real era tan destacado que

\begin{abstract}
"en el año de 1708 abolió Felipe $5^{\circ}$ la celebración de Cortes en todas las provincias de la Corona de Aragón, como en castigo de la resistencia armada que hacian a sus derechos a la corona de España en la obstinada Guerra de Sucesión. Sin este motivo ayudado de los ejércitos que combatian a su favor, no lo hubiera podido ejecutar, ni lo hubiera intentado. Entonces se vio que el cañón era la última razón de los Reyes; desde entonces perdieron aquellas provincias el privilegio y prerrogativa de establecer $\mathrm{y}$ defender sus leyes patrias y de imponerse y administrar las contribuciones públicas". ${ }^{7}$
\end{abstract}

Si bien un conflicto bélico como la Guerra de Sucesión comportó la derogación de cualquier vestigio constitucional en el Principado de Cataluña, a partir de la asociación de conceptos tales como libertad e independencia, la guerra contra las tropas francesas podía acarrear la restitución del tan anhelado

\footnotetext{
6 José Álvarez Junco, “Capmany y su Informe sobre la necesidad de una Constitución (1809)", op. cit., pp. 546-549; y Ernest Lluch, Las Españas vencidas del siglo XVIII: claroscuros de la Ilustración, Barcelona, Crítica, 1999, p. 90.

7 José Álvarez Junco, "Capmany y su Informe sobre la necesidad de una Constitución (1809)", op. cit., pp. 546-547.
} 
régimen político constitucional. Tal y como se desprende del Manifiesto de la Central a la nación española publicado a principios del mes de noviembre de 1809: "Españoles (...) la Providencia ha querido que en esta crisis terrible no pudieseis dar un paso hacia la independencia sin darlo también hacia la libertad. (...) Sí, españoles, vais a tener vuestras Cortes". ${ }^{8}$ Ciertamente, a principios del siglo XIX, el historicismo se convirtió en la expresión de la necesidad de legitimación que requería cualquier formulación política que transpirase ideas de renovación o de racionalismo. ${ }^{9}$ ¿Qué mejor ejemplo que el ulterior proceso constituyente doceañista de signo reformista y liberal?

El 3 de diciembre de 1809 Antonio de Capmany remitió a la Comisión de Cortes "un compendio de la práctica y modo de convocar Cortes en el reino de Aragón y en el de Valencia", y quince días después "una noticia del modo y formalidad con que se celebran los congresos nacionales en Cataluña". ${ }^{10}$ Dichos trabajos se publicaron póstumamente en la obra titulada Práctica y estilo de celebrar Cortes en el reino de Aragón, principado de Cataluña, y reino de Valencia y una noticia de las Castillas y Navarra. ${ }^{11}$ A partir del efectivo recurso historicista Capmany defendió el vínculo entre las Cortes catalanas medievales de representación estamental y las futuras gaditanas haciendo uso de las históricas experiencias de los territorios de la antigua Corona de Aragón con la finalidad de aportar un antecedente autóctono válido de un constitucionalismo moderno, evitando así la habitual descalificación de los individuos más reaccionarios que presentaban cualquier idea de constitucionalismo como una inadmisible contaminación ideológica de la Revolución francesa:

\begin{abstract}
"No presento el estado político de la Corona de Aragón por modelo perfecto de una Constitución, tal como acaso necesitan los pueblos para alcanzar y afianzar la última felicidad y libertad del hombre en sociedad (...). Lo presento para mostrar al mundo poco instruido de nuestra antigua legislación hasta qué grado de libertad llegaron las provincias de aquella corona en siglos que hoy se les quiere llamar góticos, por no decir bárbaros, y cual en aquellos tiempos no había gozado ninguna nación en un gobierno monárquico". ${ }^{12}$
\end{abstract}

8 Archivo de la Corona de Aragón, en adelante ACA, G. I., Caja 8, Manifiesto de la Central a la nación española sobre comienzos de las Cortes en marzo próximo (1810), Sevilla, 2 de noviembre de 1809.

9 Lluís Roura i Aulinas, “Guerra de Independencia e inicios de Revolución”, Cuadernos de Historia Moderna, nº VII, 2008, p. 82.

10 Consultar José María Portillo Valdés, Revolución de nación. Orígenes de la cultura constitucional en España, 1780-1812, Madrid, Centro de Estudios Políticos y Constitucionales, 2000, pp. 266 y ss.

11 Antonio de Capmany, Práctica y estilo de celebrar Cortes en el Reino de Aragón, Principado de Cataluña y Reino de Valencia, y una noticia de las de Castilla y Navarra, Madrid, Imprenta de José Collado, 1821. El texto manuscrito de este compendio puede consultarse en la Real Academia de la Historia, en adelante RAH, Legajo 11-7980-18. Además, la obra cuenta con una reciente edición facsímil que contiene un estudio elaborado por Eva Serra y Josep Fontana.

12 Antonio de Capmany, Práctica y estilo de celebrar Cortes en el Reino de Aragón, Principado de Cataluña y Reino de Valencia, y una noticia de las de Castilla y Navarra, op. cit., pp. IV-V; y Eva Serra y Josep Fontana, Práctica y estilo de celebrar cortes en el reino de Aragón, principado de Cataluña y reino de Valencia y una noticia de las de Castilla y Navarra. Estudi de l'obra realitzat per Eva Serra i Josep Fontana, edición facsimil, Barcelona, Editorial Base, 2007, pp. 56-57. 
De este modo, con el objetivo de erradicar el denostado despotismo, a partir de una evidente exaltación romántica del período medieval, Capmany enalteció el carácter consuetudinario de las constituciones catalanas, la doctrina contractual limitadora del poder regio propia del sistema político pactista y las principales instituciones del Principado, o sea, las Cortes, la Diputación del General o Generalidad y el organismo municipal barcelonés conocido históricamente como Consejo de Ciento.

Asimismo, invocando al tradicional mandato imperativo de las antiguas Cortes catalanas, el 13 de agosto de 1810 la Junta Superior de Observación y Defensa del Principado de Cataluña hizo llegar a los diputados catalanes unas Instrucciones redactadas por el secretario y futuro parlamentario Felipe Aner destinadas a procurar instituir un régimen constitucional que mejorase substancialmente el marco político y jurídico del territorio catalán: "Cataluña no sólo conservar sus privilegios y fueros actuales [derecho privado consuetudinario] sino también recobrar los que disfrutó en el tiempo en que ocupó el Trono Español la augusta Casa de Austria”.13

Sirva de ejemplo que en las Cortes de Cádiz, Ramón Lázaro de Dou, el primer presidente electo del Congreso, prosiguiendo con la nostalgia medieval tan característica de la ideología liberal española ${ }^{14}$, vindicó efusivamente el modelo político pactista de la antigua Corona de Aragón al aseverar que "cuando teniamos la libertad y la Constitución que quieren hacer revivir las Cortes [gaditanas], los Reyes y nosotros éramos más felices”. Significativamente, el canciller de la Universidad de Cervera encumbró las constituciones catalanas como normas básicas que garantizaban una serie de prerrogativas fundamentales hasta el punto de preguntarse: “¿En dónde están las Constituciones de Cataluña?"15. De hecho, según el criterio del diputado catalán en

\begin{abstract}
"Cataluña. Alli estaba perfectamente separado el Poder ejecutivo del judiciario: el pacto social, no solo era tácito, sino expreso: el Rey juraba la observancia de las leyes y privilegios de la Constitución: el juramento debía prestarse personalmente dentro de la misma provincia, sin que se dispensase en esto al grande Emperador Carlos $\mathrm{V}$ ni a otro Monarca: una de las primeras diligencias de las Cortes era el nombramiento de jueces de agravios para decidir de plano todas las quejas que se presentasen de haber vulnerado el Rey a sus oficiales los privilegios de la provincia, de algún particular o cuerpo (...) todo esto, con muchas cosas más, análogas al mismo fin, quedó entorpecido o como adormecido de resultas de la Guerra de Sucesión”.16
\end{abstract}

Así pues, según el razonamiento de Dou, la división de poderes, en este caso particular, entre el ejecutivo y el judicial a través de la figura del juez de agravios,

13 ACA, G.I., Vol. 17, fs. 196-196r. Exposición de las principales ideas que la Junta Superior del Prdo. de Cataluña cree conveniente manifestar a los S. Diputados de la Provincia que en representación de la misma pasan al Congreso de las próximas Cortes, Tarragona, 13 de agosto de 1810.

14 Véase José Manuel Nieto Soria, Medievo constitucional. Historia y mito politico en los origenes de la España Contemporánea (ca. 1750-1814), Madrid, Akal, 2007; y Faustino Martínez Martínez, "De la constitución histórica a la historia constitucional. El medievo como imaginario politico (siglos XVIII-XIX)”, Historia Constitucional, no 10, 2009, pp. 511-527.

15 DSC, núm. 132, 5 de febrero de 1811 , p. 502.

16 DSC, núm. 96, 31 de diciembre de 1810, p. 271. 
se convirtió en el procedimiento esencial para impedir el despotismo impuesto a partir de la derrota catalana de 1714. El jurista barcelonés, haciendo uso de un vocablo extraído de la obra El contrato social de Jean Jacques Rousseau, se refirió al pacto social que legitimaba la soberanía compartida entre el rey y las Cortes catalanas mediante el ceremonial regio establecido en las Cortes de Barcelona del año 1300 convocadas por Jaime II, o sea, en concreto, a la coronación del soberano a cambio de jurar fidelidad a las constituciones catalanas, más si cabe, cuando se instituyó la explícita condición de contar con la presencia del monarca en territorio catalán. ${ }^{17}$

Por su parte, los diputados catalanes Jaime Creus y Antonio de Capmany recurrieron a la tradición constitucional del Principado como legítimo referente para validar la protección y la autonomía de los parlamentarios doceañistas. E1 eclesiástico Creus declaró que "yo soy diputado de una provincia [Cataluña] que ha sabido sostener la libertad de sus diputados en las Cortes"18 y el académico Capmany, vinculando directamente las históricas Cortes catalanas con las Cortes de Cádiz, ensalzó la amplitud de los poderes que "se libraban antiguamente para sus Cortes en Cataluña, y en aquellas no se trataba menos que de <hacer leyes nuevas, y derogar o alterar las antiguas $>$, como lo manifiestan los actos y capitulos de Cortes estampados en el volumen de las Constituciones de Cataluña", hasta el extremo de aseverar que "en las Cortes antiguas de Cataluña todo se dejaba al arbitrio y discreción de los Diputados". ${ }^{19}$

En dicho sentido, en el Discurso Preliminar a la Constitución de 1812, elaborado en su mayor parte por el diputado asturiano Agustín de Argüelles y en menor medida por el parlamentario catalán José Espiga y Gadea, hallamos abundantes referencias a la tradición constitucional de la antigua Corona de Aragón, seguramente, fruto de los vastos conocimientos que atesoraba el eclesiástico Espiga en historia del derecho catalán. En primer lugar, tal y como hemos podido observar en el decreto de 22 de mayo de 1809 de la Junta Central y el Informe redactado por Antonio de Capmany, con el objetivo de evitar las antipatrióticas acusaciones de afrancesamiento los autores del Discurso sostuvieron que "aquellos que, poco versados en la historia y legislación antigua de España, creerán tal vez tomado de naciones extrañas [de Inglaterra y, especialmente, de la Francia napoleónica] (...) todo lo que no ha estado en uso de algunos siglos a esta parte [a partir de la dinastía Habsburgo], o lo que se oponga al sistema de gobierno adoptado entre nosotros después de la Guerra de Sucesión [dinastía borbónica]". Nada más lejos de la realidad, ya que, como es bien sabido, declararon que "nada ofrece la Comisión [constitucional] en su proyecto que no se halle consignado del modo más auténtico y solemne en los diferentes cuerpos de la legislación española". Hasta el punto de asegurar que "la lectura de los historiadores aragoneses, que tanto se aventajan a los de Castilla, nada deja que desear al que quiera instruirse de la admirable constitución de aquel reino". De hecho, según el dictamen de Argüelles y de Espiga "ninguna nación de Europa

17 Lluís Ferran Toledano González, "El projecte català per a Espanya. La classe dirigent catalana $i$ el procés constitucional de Cadis (1808-1814)", Afers, n 68, 2011, pp. 94-95; y Montserrat Bajet Royo, El jurament $i$ el seu significat juridic al Principat segons el dret general de Catalunya (segles XIII-XVIII), Barcelona, Universidad Pompeu Fabra, 2009, p. 108.

18 DSC, núm. 920, 23 de julio de 1813, p. 5785.

19 DSC, núm. 751, 21 de enero de 1813, p. 4422. 
puede acaso presentar leyes más filosóficas ni liberales, leyes que protejan mejor la seguridad personal de los ciudadanos, su honor y su propiedad, si se atiende a la antigüedad de su establecimiento, que la admirable Constitución de Aragón”. No obstante, el régimen borbónico derogó el sistema constitucional de la antigua Corona de Aragón que, por su carácter contractual, además de limitar el poder regio, incluso estaba facultado para desposeer a un monarca de su corona, así como sucedió en el Principado catalán en el marco de la conocida como Guerra Civil Catalana: "notable suceso de Cataluña en el año 1462, en que los estados de aquel Principado, después de haberse resistido a don Juan II de Aragón, le depusieron solemnemente del trono [y su sobrino Enrique IV de Castilla fue nombrado conde de Barcelona]". Precisamente, una de las fórmulas utilizadas en los juramentos por los nobles catalanes primero ante los soberanos de la Corona de Aragón y, posteriormente, ante los reyes de la Monarquía Hispánica, recogía la noción que el poder del monarca derivaba del pueblo al cual servía: "Nós, que valem tant com vós, jurem davant vós que no sou millor que nós, que junts valem més que vós, i que us acceptem com rei i sobirà sempre que respecteu les nostres llibertats i lleis, però si no, no". Por tales motivos Agustín de Argüelles y José Espiga llegaron a afirmar que "Aragón fue en todas sus instituciones más libre que Castilla. El Rey en aquel reino no podia resistir abiertamente las peticiones de las Cortes, que pasaban a ser leyes si el reino insistía". Máxime cuando la iniciativa legislativa de las Cortes de la antigua Corona de Aragón y la condición de leyes pactadas se hizo patente mediante "la fórmula que se usaba para su publicación (...) El Rey, de voluntad de las Cortes, estatuesce y ordena". De esta manera, el Congreso gaditano perfectamente se podia inspirar en unas Cortes aragonesas instituidas para impedir el despotismo regio debido a que "su objeto era oponerse abiertamente a la usurpación que hacía el rey o sus ministros de los fueros o libertades del reino". Especialmente cuando "en Aragón se miraba la frecuente convocación de Cortes como el medio más eficaz de asegurar el respeto y la observancia de las leyes". Inclusive, los autores del Discurso pudieron aseverar en relación a las limitaciones a la autoridad del rey doceañista impuestas por la comisión constitucional que "ni aun en esto pretende ser original: los fueros de Aragón le ofrecieron felizmente la fórmula de las restricciones". De este modo, una vez que el despotismo ejercido por las dinastias extranjeras de los Austrias y Borbones causara "un olvido casi general de nuestra verdadera constitución" el proceso constituyente gaditano esencialmente pretendia restituir la histórica tradición constitucional nacional. ${ }^{20}$

Al respecto, el parlamentario catalán Felipe Aner no pudo ser más explícito al afirmar que "los diputados de las cortes actuales tenemos misión expresa para restablecer la Constitución de la Monarquía [pese a no estar redactada en documento alguno], cuya inobservancia y olvido debía considerarse el origen de todos los males". ${ }^{21}$ Con tal afirmación, si bien las leyes fundamentales ${ }^{22}$ eran

20 Agustín de Argüelles, Discurso preliminar a la Constitución de 1812, estudio introductorio a cargo de Luis Sánchez Agesta, Madrid, Centro de Estudios Constitucionales, 1981, pp. 22, 34, 37, 68-72, 91 y 96. Precisamente, en la Junta de Legislación establecida por la Junta Central se acordó que "El Rey promulgará las leyes sirviéndose para ello de la siguiente fórmula: $<\mathrm{El}$ Rey, de consentimiento y voluntad de las Cortes, establece y ordena...>". 14 Acuerdo (17 de diciembre de 1809). Ignacio Fernández Sarasola, La Constitución de Cádiz. Origen, contenido y proyección internacional, Madrid, Centro de Estudios Políticos y Constitucionales, 2011, p. 344.

${ }^{21}$ DSC, núm. 472, 18 de enero de 1812, pp. 2652-2653. 
territorialmente diversas y casi no las había comunes al cuerpo entero de la Monarquía Hispánica, el jurista Aner, precisamente, a partir de los preceptos emanados del Discurso preliminar destinados a explicar el texto constitucional, se sirvió del legado normativo medieval para justificar la limitación del poder monárquico y la seguridad de la libertad politica y civil. ${ }^{23}$

\section{II.- LA CRÍTICA A LA DERIVA DESPÓTICA DE LOS AUSTRIAS}

La Monarquía dual o compuesta por razón de la unión de la Corona de Castilla y la de Aragón permitió a cada uno de éstos reinos históricos conservar sus leyes, privilegios e instituciones. De esta forma, la unidad era meramente simbólica entorno a un monarca que gobernaba a partir del sistema de Consejos establecidos en la Corte e integrados por oficiales naturales de los territorios respectivos, la conocida como estructura polisinodial. ${ }^{24}$ Tal y como reconoció el jurista Felipe Aner era una "época en que cada provincia constituía una Monarquía separada".25 Eso sí, de acuerdo a la interpretación de insignes liberales como el poeta Manuel José Quintana ${ }^{26}$ o Francisco Martínez Marina en la Corona de Castilla se impuso un régimen despótico a partir del reinado de Carlos I, ya que el Emperador suprimió la antigua monarquía moderada o limitada por las Cortes y la ley ${ }^{27}$ una vez que venció militarmente a los comuneros en la Guerra de las Comunidades de Castilla (1520-1522). ${ }^{28}$

Precisamente, con el objetivo de defender la institución de una Diputación permanente de Cortes el diputado catalán Antonio de Capmany hizo referencia a

22 Consultar Santos Manuel Coronas González, "Las Leyes Fundamentales del Antiguo Régimen (Notas sobre la Constitución histórica española)”, Anuario de Historia del Derecho Español, $\mathrm{n}^{\circ}$ 65, 1995, pp. 127-217.

23 José María Portillo Valdés, Revolución de nación. Orígenes de la cultura constitucional en España, 1780-1812, op. cit., 2000, p. 370.

24 Véase Antonio Álvarez-Ossorio y Bernardo José Garcia, (edit.), La Monarquía de las Naciones: patria, nación y naturaleza de la Monarquía de España, Madrid, Fundación Carlos de Amberes, 2004; y John H. Elliott, "Una Europa de monarquías compuestas". España, Europa y el mundo de ultramar (1500-1800), Madrid, Taurus, 2010, pp. 29-54.

25 DSC, núm. 249, 7 de junio de 1811, p. 1206.

26 En una oda escrita "al Panteón del El Escorial" Quintana inauguró la visión negativa de los Austrias como "déspotas" y "tiranos" que va a caracterizar a todo el pensamiento liberal español. El mismo Carlos V asume su propia culpabilidad y la de su hijo Felipe II: "Yo los desastres de España comencé y el triste llanto cuando, expirando en Villalar Padilla, morir vió en él su libertad Castilla. Tú los seguiste, y con su fiel Lanuza cayó Aragón gimiendo". La oda de Manuel José Quintana se puede consultar en Albert Dérozier (edit.), Poesías Completas, Madrid, Turner, 1969), p. 292. Citado por Carlos Forcadell, "El mito del Justicia en el imaginario del liberalismo español", en Pere Anguera (coord.), Simbols $i$ mites a l'Espanya contemporània, Edicions del Centre de Lectura de Reus, Reus, 2001, pp. 217.

27 Francisco Martínez Marina, Teoría de las Cortes. Grandes Juntas Nacionales de los Reinos de León y Castilla. Momentos de su constitución política y de la soberanía del pueblo, con algunas observaciones..., Madrid, Imp. de Fermín Villalpando, 1813, p. 7.

28 En la conocida como "Ley perpetua" de 1520 la Junta comunera expuso un programa politico fuertemente constitucionalista porque exigía que el rey observase las leyes del reino, a la vez que propugnaba unas Cortes más activas. Xavier Gil Pujol, "Concepto y práctica de república en la España moderna. Las tradiciones castellana y catalanoaragonesa”, Estudis, $\mathrm{n}^{\circ} 34,2008$, pp. 117-118. 
"la guerra de los comuneros". El ejemplo no era casual ni aleatorio, ya que en un contexto marcado por el historicismo prerromántico el conflicto de los comuneros se convirtió en todo un simbolo de la lucha hasta la muerte de los castellanos contra el absolutismo de los Austrias. Singularmente, cabe recordar la decapitación de sus principales líderes: Padilla, Bravo y Maldonado. En el Congreso gaditano Capmany constató como "en Cataluña no se atrevió Carlos V, sin embargo de sus deseos de romper obstáculos a su voluntad y poderío, a quebrantar las leyes y estatutos patrios, como lo hizo en la Corona de Castilla, siendo así que era Monarca de toda España”. A diferencia del Principado catalán, en opinión del historiador barcelonés, Castilla no pudo impedir la inobservancia de la ley porque “jamás mantuvo permanente diputación”. En cambio, el archivero catalán documentó que "había esta diputación en Cataluña [Diputación del General o Generalidad] y en toda la Corona de Aragón, establecida por leyes constitucionales de la tierra, que era el custodio de ellas de unas Cortes a otras. Este respetable cuerpo nacional salvó aquellas provincias de la arbitrariedad de los Reyes, y mantuvo invulnerables sus fueros y libertades contra cualquier tentativa de la corte". ${ }^{29}$ De esta forma, los parlamentarios catalanes apelaron al pasado para evidenciar que la soberanía pertenecía en esencia y en exclusiva a la nación, pero fue arrebatada por el despotismo imperial de los Habsburgo en la Corona de Castilla y de los Borbones en la Corona de Aragón.

En palabras del historiador John H. Elliott "los Austrias eran reyes absolutos en Castilla y monarcas constitucionales en Cataluña". 30 De hecho, desde el año 1538 los brazos eclesiástico y nobiliario dejaron de ser convocados cuando se celebraban Cortes y la facultad legislativa quedó en manos de la Corona prácticamente de manera exclusiva, hasta el punto que el papel de las Cortes de Castilla se redujo a una mera función ceremonial en la proclamación de los nuevos reyes. Indudablemente, se ha de tener en consideración que los gobernantes de la dinastía Habsburgo adoptaron la tendencia general europea que era partidaria de incrementar el poder de los monarcas y, de esta manera, debilitar las potestades de la nobleza. ${ }^{31}$ Como muestra, en las Cortes de Cádiz el parlamentario catalán Jaime Creus declaró que "en España la arbitrariedad de los Reyes ha progresado en razón de la disminución de facultades en los señores. Los Reyes de la dinastía austriaca entonces principiaron a mandar arbitrariamente a los pueblos". ${ }^{32}$ Ciertamente, en tiempos de los Habsburgo, la Corte General de Cataluña, la primera institución legislativa, fiscal y de gobierno del Principado, fue convocada cada vez con menor asiduidad, hasta el punto que durante poco más de un siglo (1599-1701) en ninguna ocasión las Cortes catalanas se pudieron concluir, provocando una significativa parálisis normativa que impidió atender a las necesidades de la sociedad catalana respondiendo a las nuevas realidades politicas, económicas, jurídicas y administrativas. De forma manifiesta, la periodicidad en la convocatoria de las Cortes es determinante para apreciar el progresivo fortalecimiento del poder regio en detrimento del legislativo.

29 DSC, núm. 371, 8 de octubre de 1811, p. 2018.

30 John H. Elliott, La rebelión de los catalanes. Un estudio sobre la decadencia de España (15981640), Madrid, Siglo XXI, 1982, pp. 20-21.

31 Xavier Gil Pujol, "Concepto y práctica de república en la España moderna. Las tradiciones castellana y catalanoaragonesa”, op. cit., p. 118.

32 DSC, núm. 254, 12 de junio de 1811, p. 1250. 
Tal y como nos reveló el cronista catalán Antonio de Capmany cuando rememoró que en las Cortes celebradas en Barcelona en 1283 bajo el reinado de Pedro el Grande se acordó convocarlas "todos los años" mediante el enunciado "Que el señor Rey faga Cort general de aragoneses en cada un año una vegada", hasta que se confirió la convocatoria "a la voluntad del Rey, y perdiendo el período que antes guardaban fueron menos frecuentes, pues pasaban muchos años sin haberlas". 33

Asimismo, en el Congreso gaditano Capmany denunció el carácter patrimonial de la Monarquía Hispánica bajo el reinado de los Austrias, al constatar que "sin excluir al mismo Felipe II, que era tan español y tan empeñado en extender su nombre en las cuatro partes del mundo, la palabra Patria jamás ha salido de boca de Soberano alguno: <mi corona, mis Estados, mis vasallos>, son los únicos nombres que han pronunciado para defender sus derechos, $\mathrm{y}$ alguna vez para abandonarlos. ¡Lamentable recuerdo para los que vivimos y lo padecemos!". ${ }^{34}$ A pesar de que Antonio Capmany y Montpalau descendia de una familia austriacista que padeció la represión borbónica en forma de exilio ${ }^{35}$ temporal a tierras italianas una vez finalizada la Guerra de Sucesión no dejó de rememorar la traición protagonizada por el Archiduque Carlos de Habsburgo en 1711 cuando abandonó a los catalanes para ocupar el trono del Imperio Austríaco a causa del fallecimiento de su hermano José I. Más si cabe cuando en dicho acaecimiento se halla la génesis de los tratados de Utrecht, Rastatt y Baden (1713-1715) ${ }^{36}$ que pusieron fin a la Guerra de Sucesión sin garantizar la preservación del sistema político-institucional pactista catalán ${ }^{37}$, pese a los compromisos adquiridos de conservar el constitucionalismo en los acuerdos firmados con Inglaterra (Pacto de Génova, 20 de junio de 1705). ${ }^{38}$

Los Austrias, no satisfechos con controlar los principales resortes de poder en Castilla, aunque estaban obligados a respetar el particular sistema juridico de cada reino, a lo largo de los siglos XVI y XVII intentaron erradicar los privilegios y los fueros de los territorios de la antigua Corona de Aragón, como fue el caso de la rebelión de las Germanías en los reinos de Valencia y Mallorca (1520-1522); las

33 DSC, núm. 362, 29 de septiembre de 1811, p. 1950.

34 DSC, núm. 455, 1 de enero de 1812, p. 2518.

35 Consultar Agustí Alcoberro i Pericay, L'exili austriacista (1713-1747), Barcelona, Fundació Noguera, 2 Vols, 2002.

36 Véase Joaquim Albareda i Salvadó (edit.), El declive de la Monarquía Española y del imperio español, Barcelona, Crítica, 2015; Virginia León Sanz (coord.), “1713. La Monarquía de España y los Tratados de Utrecht”, Cuadernos de Historia Moderna, no 12, 2013, pp. 11-210; y Bernardo J. Garcia Garcia, En nombre de la paz. La Guerra de sucesión española y los tratados de Madrid, Utrecht, Rastatt y Baden, 1713-1715, Madrid, ACE, Fundación Carlos de Amberes, 2014.

37 En el artículo XII del tratado de paz entre Inglaterra y Felipe V, del 13 de julio de 1713, Felipe de Anjou concedió a los catalanes, cínicamente, "todos aquellos privilegios que poseen los habitantes de las dos Castillas". Joaquim Albareda i Salvadó, "El <cas dels catalans>: Del pacte de Gènova a l'<equilibri> europeu, de 1713”, Pedralbes, n 18, 1998, p. 306.

38 En el texto se adujo que Felipe V no respetó las constituciones catalanas para justificar la nulidad del juramento de fidelidad efectuado en las Cortes de 1701-1702. "Tratado de Alianza entre la serenísima Reina Ana de Inglaterra y el Principado de Cataluña”. Josep Maria Torras i Ribé, Escrits polítics del segle XVIII. Tom II. Documents de la Catalunya sotmesa, Vic, Eumo/IUHJVV, 1996, pp. 74-81. 
Alteraciones de Aragón de 1591 y la invasión de tropas castellanas durante el reinado de Felipe $\mathrm{II}^{39}$, destacando sobre manera las restricciones aprobadas en las Cortes de Tarazona de 1592 a la figura del Justicia Mayor de Aragón, encargado de velar por la legalidad de las leyes y normas forales, así como a las atribuciones de la Generalidad de Aragón, especialmente en materia militar; y, substancialmente, el intento de reforzar el poder regio por iniciativa del Conde Duque de Olivares ${ }^{40}$ en tiempos de Felipe IV, tal y como puso de manifiesto el diputado catalán Antonio de Capmany: "Era el país [antigua Corona de Aragón] que tenía una Constitución, la cual, por los nudos con que estaba ligada, era por sí misma indisoluble. Y así perseveró, invulnerable hasta que las armas de Felipe II en Aragón [ejecución mediante decapitación por orden del monarca del Justicia Mayor de Aragón Juan de Lanuza V o el Mozo (20 de diciembre de 1591)41], y las de Felipe IV en Cataluña [Guerra dels Segadors (1640-1652)], intentaron darle algunos asaltos; y últimamente, las de Felipe V la derribaron con mayor poder, por aquel derecho de conquista que se atribuyó con la Guerra de Sucesión [17051714]". ${ }^{42}$ El relato del erudito Capmany daba cuenta de un inquebrantable sistema constitucional y pactista forjado en el medievo que únicamente podia sucumbir ante agresiones bélicas exteriores motivadas por el cada vez más incesante anhelo de imponer un uniforme y centralista régimen absolutista en el conjunto de la Monarquía Hispánica que permitiera la concentración de todas las potestades en manos del rey.

Si bien hemos podido comprobar como el Emperador Carlos no se atrevió a quebrantar las constituciones, leyes y privilegios de Cataluña, un sucesor suyo, Felipe IV, apodado el Grande o el Rey Planeta, perteneciente a los Austrias menores, guiado por los consejos del Conde Duque de Olivares, mediante la célebre Unión de Armas (1626) ${ }^{43}$ destinada a conseguir que los diversos "Reinos, Estados y Señoríos" contribuyeran en hombres y dinero a su defensa en proporción a su población y su riqueza ${ }^{44}$, si que se aventuró a socavar las prerrogativas militares consignadas en las constituciones catalanas que impedian a las tropas del Principado el servicio más allá de sus propias fronteras, máxime cuando tácitamente unas "reglas muy estrictas disponían el reclutamiento y la

39 Antoni Simon i Tarrés, Els orígens ideològics de la Revolució Catalana de 1640, Barcelona, Publicacions de l'Abadia de Montserrat, 1999, pp. 183-194.

40 Don Gaspar de Guzmán y Pimentel Ribera y Velasco de Tovar (Roma, 6 de gener de 1587Toro, 22 de juliol de 1645). Consultar John H. Elliott, El Conde-Duque de Olivares. El politico en una época de crisis, Barcelona, Crítica, 1990.

41 Véase Encarna Jarque Martínez, Juan de Lanuza, Justicia de Aragón, Zaragoza, DGA, 1991.

42 Antonio de Capmany, Práctica y estilo de celebrar Cortes en el Reino de Aragón, Principado de Cataluña y Reino de Valencia, y una noticia de las de Castilla y Navarra, op. cit., p. VI; y Eva Serra y Josep Fontana, Práctica y estilo de celebrar cortes en el reino de Aragón, principado de Cataluña $y$ reino de Valencia y una noticia de las de Castilla y Navarra. Estudi de l'obra realitzat per Eva Serra $i$ Josep Fontana, edición facsímil, Barcelona, Editorial Base, 2007, p. 60.

43 En las Cortes de Cádiz el proyecto de la Unión de Armas del Conde Duque se materializó en el Título VIII de la Constitución de 1812: “De la fuerza militar nacional”. En concreto, mediante el artículo 356: "habrá una fuerza militar nacional permanente de tierra y de mar para la defensa exterior del Estado, y la conservación del orden interior". Constitución politica de la Monarquía española. Promulgada en Cádiz a 19 de marzo de 1812, Cádiz, Imprenta Real, 1812, p. 54.

44 John H. Elliott y José F. De la PEÑA, Memoriales y Cartas del Conde Duque de Olivares. I. Politica interior: 1621 a 1627, Madrid, Alfaguara, 1978, p. 186. 
utilización de las tropas"45, tal y como se evidenció en las inacabadas Cortes catalanas de 1626-1632. ${ }^{46}$

No obstante, en 1635 la declaración de guerra de Luís XIII de Francia a Felipe IV trasladó el teatro bélico a Cataluña, reactivándose así el intento de ejecutar la Unión de Armas. Asimismo, la llegada de un cuantioso contingente de tropas a tierras catalanas, unos 40.000 soldados, mayoritariamente castellanos, ocasionó graves inconvenientes porque fueron percibidos como un verdadero ejército de ocupación que llegado el momento podría cercenar el autogobierno del Principado, hasta el punto de incidir decisivamente en los dramáticos sucesos acaecidos en el Corpus de Sang de 1640 que propiciaron el estallido de la Guerra dels Segadors. ${ }^{47}$ De esta manera, Capmany utilizó el recurso historicista para rememorar el alzamiento del pueblo catalán frente al creciente despotismo monárquico de los Habsburgo. Eso sí, a pesar de la ulterior conquista militar de Cataluña por parte de las tropas castellanas, Felipe IV, una vez que fue reconocido como legítimo soberano, juró respetar las constituciones, leyes y privilegios catalanes y, efectivamente, mantuvo prácticamente intacto el sistema pactista. Únicamente el monarca se preocupó de introducir un rígido sistema de censura previa en las insaculaciones para las plazas de la Diputación del General y del Consejo de Ciento. ${ }^{48}$ Seguramente, la conservación del consuetudinario corpus jurídico y del contractual marco político-institucional catalán por parte de los Austrias explica que en las Cortes de Cádiz, en concreto, en la discusión del artículo 171 que regulaba las facultades del rey constitucional, en referencia a la novena atribución que permitía al soberano "disponer de la fuerza armada, distribuyéndola como más convenga", el diputado catalán Felipe Aner considerara "de suma necesidad este párrafo", ya que dicha potestad "debía dársele al Rey para evitar las quejas y reclamaciones de las provincias; alego los disturbios de Cataluña en tiempos de Felipe IV, y las largas y enérgicas contestaciones que con dicho Rey tuvieron los habitantes de aquella provincia por la permanencia de las tropas en ella". ${ }^{49}$ Conforme la intervención del jurista Aner el monarca además de reinar habia de gobernar, por tanto, bajo ningún concepto podía ceder el ejecutivo a un valido, favorito o privado ${ }^{50}$, precisamente, como había sucedido durante el reinado de Felipe IV.

45 John H. Elliott, La rebelión de los catalanes. Un estudio sobre la decadencia de España (15981640), Madrid, Siglo XXI, 1982, p. 185.

46 Antoni Simon i Tarrés, Els origens ideològics de la Revolució Catalana de 1640, Barcelona, Publicacions de l'Abadia de Montserrat, 1999, pp. 140-152; y Joan Lluís PALOS, "Les idees $i$ la revolució catalana de 1640", Manuscrits, n 17, 1999, pp. 277-292.

47 Véase Eva Serra (coord.), La revolució catalana de 1640, Barcelona, Crítica, 1991; y Xavier Torres Sans, La Guerra dels Segadors, Lleida, Pagès Editors/Eumo, 2006.

48 Jon Arrieta, "Catalunya entre els segles XVII i XVIII. Reflexions sobre un canvi", Revista de Dret Històric Català, nº 7,2007 , p. 96.

49 DSC, núm. 378, 15 de octubre de 1811, p. 2085.

50 “(...) Los privados [por ejemplo, el cardenal Alberoni, el conde de Floridablanca o Manuel Godoy], cuyos crímenes ocupan algún lugar en la historia, o fueron víctima del pueblo, o del poder de sus rivales, o del enojo de los príncipes desengañados: y así casi todos murieron en un cadahalso". Antonio de Capmany, Centinela contra franceses. Parte segunda, Madrid, Imprenta de Sancha, 1808, p. 21. 
De hecho, en buena medida, los parlamentarios catalanes que asistieron al Congreso gaditano ${ }^{51}$ atribuyeron el histórico y progresivo despotismo regio a los agentes gubernamentales. ${ }^{52} \mathrm{Al}$ ser inviolable la figura del monarca ${ }^{53}$, de manera inexorable, la responsabilidad de la degeneración en clave absolutista se imputó a un ministro corrupto, a un valido manipulador, a un favorito maquiavélico o a un arribista privado. De esta forma, todos los errores del soberano se atribuyeron al engaño de un malicioso consejero. ${ }^{54}$ Tal y como se desprende de las palabras del parlamentario del Principado catalán y miembro de la comisión constitucional José Espiga: "ha sucedido que un Ministro ha llegado por sus malas artes a abusar de la bondad de un Rey". ${ }^{55}$ Precisamente, la dignidad de la catedral de Lérida participó de la redacción de un Discurso Preliminar que aseveró que "la nación (...) [era] desgraciada por haberse dejado despojar por los ministros y favoritos de los reyes de todos los derechos e instituciones que aseguraban la libertad de sus individuos". 56

En el contexto de la elaboración del reglamento interino del Consejo de Regencia para determinar las atribuciones del poder ejecutivo ${ }^{57}$, en particular, en la discusión del primer artículo -"los Secretarios del Despacho formarán una Junta"- del segundo capítulo, se evidenció la ingente desconfianza que profesaban los diputados catalanes respecto a la gestión ministerial, de acuerdo al amargo recuerdo que dejaron en la memoria colectiva de los catalanes diversos ministros que ejercieron su cargo en tiempos de los Austrias y los Borbones. De forma categórica, Felipe Aner se opuso al articulado porque según su criterio "adoptando el plan se verificaría con mayor extensión el despotismo y arbitrariedad que se quiere evitar", más si cabe cuando "los Ministros tienen una

51 Las biografias de los diputados catalanes se pueden consultar en Mikel Urquijo Goitia (coord.), Diccionario biográfico de parlamentarios españoles de las Cortes de Cádiz (1810-1814), Madrid, Cortes Generales, 2010.

52 De manera elocuente en la conocida como Consulta al País el obispo de Lérida Jerónimo María de Torres aseveró que "el diferente modo de pensar de los soberanos, el interés de los que le rodean, y sobre todo, la adulación y los privados, que por mil vías tortuosas buscan solamente su interés propio a costa de la nación y del soberano mismo que les protege, son el origen de las variaciones continuas, modificaciones, interpretaciones y derogaciones de hecho de las leyes más saludables en perjuicio de la república y del príncipe que la gobierna". ACD, Legajo 6, núm. 21. Lérida, 17 de diciembre de 1809. Miguel Artola, Los origenes de la España contemporánea, Madrid, Instituto de Estudios Politicos, 1959, Vol. II, p. 179.

53 La sacralización del monarca se puso de manifiesto en el capítulo I - "De la inviolabilidad del Rey, y de su autoridad"- del Título IV. De hecho, en el artículo 168 se declaró que "la persona del Rey es sagrada e inviolable, y no está sujeta a responsabilidad". DSC, núm. 372, 9 de octubre de 1811, p. 2024. Constitución politica de la Monarquía española. Promulgada en Cádiz a 19 de marzo de 1812, op. cit., p. 27.

54 La naturaleza moral y la condición cristianamente virtuosa que se atribuía a la figura del monarca impedía a la cultura política de principios del XIX atribuir ninguna culpa, pecado, debilidad, mala intención o error a éste. David Agrait García, "Sobre el concepto de representación en los orígenes del Constitucionalismo Hispánico: una reflexión historiográfica sobre los aspectos jurídico-politicos de la “consulta al país”, 1809-1810”, Revista Jurídica de la Comunidad de Madrid, $\mathrm{n}^{\circ} 24,2006$, p. 193.

55 DSC, núm. 457, 3 de enero de 1812, p. 2541.

56 Agustín de Argüelles, Discurso preliminar a la Constitución de 1812, op. cit., p. 78.

57 Rafael Flaquer Montequi, "El Ejecutivo en la revolución liberal”, en Miguel Artola (edit.), Las Cortes de Cádiz, Madrid, Marcial Pons, 2003, pp. 52-57. 
tendencia al despotismo". 58 A la sazón, el docto José Espiga se retrotrajo al período medieval para intentar demostrar que el Consejo de Estado no era una institución nueva, o sea, instituida por los revolucionarios franceses, en dicho sentido, conviene recordar que tenía el mismo nombre del que en Francia había creado Napoleón, atestiguando que era "una verdad demostrada desde el origen de nuestra Monarquía... nuestros Reyes acostumbraron a despachar en su Consejo todos los negocios públicos del Reino". En concreto, el diputado catalán se remontó a los tiempos de los godos, en evidente alusión al goticismo ${ }^{59}$, cuando era un Consejo de Guerra que, en época feudal, se convirtió en "Consejo del Rey... ya no eran solo militares, sino condes, prelados, ricos-homes, rentistas y políticos", hasta que "se sintió la necesidad de jurisconsultos que explicasen las dudas que se suscitaban todos los dias en los negocios de justicia"; siendo el rey Enrique III quién dispuso que "en adelante hubiese en su Consejo letrados que entendiesen en negocios contenciosos". Prosiguiendo con la disertación de José Espiga y Gadea, bajo el reinado de los Reyes Católicos las facultades del Consejo del Rey llegaron a comprender la mayor parte de las materias gobernativas hasta el punto que fue necesario dividirlo en cinco salas, iniciándose, de esta manera, la división del poder judicial del ejecutivo: "el Emperador Carlos V dispuso que letrados sabios y acreditados por sus talentos y servicios entendiesen de ellos en cuerpo separado". Justamente, en dicho momento es cuando podemos precisar la transformación del histórico Consejo en "Consejo de Estado de España, y algunas veces Consejo de Estado y de Guerra, de todos los negocios graves de la Monarquía, se fijaron las atribuciones de justicia al que se llamó desde entonces Consejo Real o de Castilla".60

Sin embargo, según el criterio del parlamentario catalán, poco después de la unión de la Corona de Castilla y la de Aragón "los Reyes empezaron a mirar con desdén y aun con fastidio la penosa carga del gobierno, los Secretarios se prevalieron de su debilidad, y abusando de la confianza separaron del Consejo de Estado el despacho para influir con más seguridad en las resoluciones". De esta manera, de acuerdo al discurso historicista, hallamos un punto de inflexión en la consolidación de la Monarquía dual o compuesta de los Austrias, coincidente cronológicamente con el transcurso de la Edad Moderna, que delimita la paulatina anulación de la constitución histórica o constitución mixta medieval por albergar mecanismos destinados a impedir el despotismo regio. En especial el Consejo de Estado61, un organismo que debido a sus funciones consultivas y fiscalizadoras actuaba de manera colegiada de eficaz contrapoder. Hasta que, en opinión del eclesiástico, "el Conde Duque [de Olivares] llegó a deprimirle de tal manera, que para impedir el influjo que no podia dejar de tener en las Reales resoluciones, consiguió que cada consejero enviase al Rey por escrito su dictamen, bien seguro de que le sería más fácil impugnar un dictamen particular

58 DSC, núm. 457, 3 de enero de 1812, p. 2539.

59 ÁLVAREZ ALONSO, Clara: "Un rey, una ley, una religión (goticismo y constitución histórica en el debate constitucional gaditano)”, Historia Constitucional, $\mathrm{n}^{\circ}$ 1, 2000, pp. 1-62.

60 DSC, núm. 390, 27 de octubre de 1811, p. 2160.

61 Véase Feliciano Barrios, El Consejo de Estado de la Monarquía española, 1521-1812, Consejo de Estado, Madrid, 1984. En relación a las Cortes de Cádiz, consultar Francisco Tomás y Valiente: "El Consejo de Estado en la Constitución de 1812", Revista del Centro de Estudios Constitucionales, núm. 21 (1995), pp. 9-22. 
que la consulta de un cuerpo respetable". ${ }^{62}$ Inequívocamente, el diputado designado por la Junta Superior de Cataluña atribuyó a las "malas artes" de los ministros el ocaso del Consejo de Estado, ya que "sorprendian y seducían a los Reyes. Entre estos se señaló sobremanera el Conde-Duque". ${ }^{63}$ De esta forma, José Espiga y Gadea fijó con precisión el auge del despotismo en el siglo XVII, centuria conocida por unos validos $^{64}$ que merced a su elevada instrucción, ambición de mando, alta categoría nobiliaria y, sobre todo, amistad con el monarca, manejaron los hilos del poder en plena consolidación de las monarquías absolutas en Europa.

Asimismo, en el caso del Conde Duque de Olivares, se ha de adicionar su politica autoritaria y centralizadora que contravenía la concepción pactista del poder característica de los territorios de la antigua Corona de Aragón. Ciertamente, según el parecer del Conde Duque se había de proceder a la uniformidad legal del heterogéneo conglomerado de reinos y provincias regulados por diferentes corpus jurídicos que integraban la Monarquía Hispánica, medida que, de facto, significaria la substitución de las constituciones, leyes y privilegios del Principado de Cataluña por el derecho público de Castilla, tal y como posteriormente se estipuló en la Nueva Planta borbónica. El planteamiento del Conde Duque de Olivares se puede resumir en el aforismo Multa regna, sed una lex: "Muchos reinos, pero una ley", 65 sin duda, la ley era la de Castilla porque en dicho lugar el poder del rey era más expeditivo que en cualquier otro reino histórico que mantuviera vigentes sus tradicionales instituciones y prerrogativas. El Conde Duque comunicó privadamente a Felipe IV sus intenciones en un célebre memorial secreto fechado el 25 de diciembre de 1624:

\footnotetext{
"Tenga Vuestra Majestad por el negocio más importante de su Monarquía, el hacerse Rey de España: quiero decir, Señor, que no se contente Vuestra Majestad con ser Rey de Portugal, de Aragón, de Valencia, Conde de Barcelona, sino que trabaje y piense, con consejo mudado y secreto, por reducir estos reinos de que se compone España al estilo y leyes de Castilla, sin ninguna diferencia, que si Vuestra Majestad lo alcanza será el Príncipe más poderoso del mundo ... [y] podrá introducir Vuestra Majestad acá y allá ministros de las naciones promiscuamente".66
}

Olivares pretendió reforzar el poder regio en detrimento del Consejo de Estado para establecer una unidad administrativa, fiscal y militar bajo el pretexto de vitalizar la politica exterior de la Monarquía Hispánica. Sin embargo, dichas medidas fueron interpretadas en los territorios de la antigua Corona de Aragón como un ataque a sus fueros $\mathrm{y}$, en el caso particular de Cataluña, como un

62 DSC, núm. 457, 3 de enero de 1812, p. 2540.

63 DSC, núm. 390, 27 de octubre de 1811, p. 2161.

64 “(...) el Valido, quien, a diferencia de otro tipo de Ministros, no comparte su posición de privilegio con ninguno, acaparando para sí la atención del Rey y haciendo ostensible su capacidad de influir sobre el monarca". Al respecto, véase José Antonio Escudero López, "Privados, validos y primeros ministros en la monarquía española de Antiguo Régimen: viejas y nuevas reflexiones", Anales de la Real Academia de jurisprudencia y legislación, n ${ }^{\circ} 39$, 2009, pp. 665-680; y Francisco Tomás y Valiente, Los validos en la monarquía española del siglo XVII, Madrid, Siglo XXI, 1982.

65 John H. Elliott, "Una Europa de monarquias compuestas". España, Europa y el mundo de ultramar (1500-1800), op. cit., 2010, pp. 45-46.

66 Gregorio Marañón, El Conde-Duque de Olivares, Madrid, Espasa-Calpe, 1936, p. 429. 
intento de someter el Principado catalán a una monarquía que cada vez emprendía una deriva más absolutista. ${ }^{67}$ Los recelos se confirmaron cuando el Conde Duque de Olivares sostuvo que "si las Constituciones [catalanas] embarazan esto, que lleve el diablo las Constituciones".68 En plena reacción defensiva del contractualismo frente las tendencias autoritarias y centralizadoras de los Austrias, el redactor del Dietario de la Junta de Brazos, reunida por Pau Claris ${ }^{69}$, no dudó en asegurar que el verdadero objetivo del gobierno de Olivares consistía en "destruir i acabar Cathaluña llevantli sos privilegis, constitucions, prerrogatives y llibertats". ${ }^{70}$ De hecho, en el propio Congreso gaditano, en directa alusión al Conde Duque de Olivares, el historiador Antonio de Capmany aseveró que "juró éste la ruina de los fueros de aquella provincia [Cataluña]". ${ }^{71}$

Sin ambages, la crisis de 1640, que además de la rebelión catalana motivó la independencia de Portugal, evidenció el fracaso del proyecto de Olivares. De acuerdo a la exposición que efectuó el diputado catalán José Espiga en el Congreso gaditano "por la muerte de este privado [1643] se restableció el Consejo en sus funciones", eso sí, "no tardó mucho en sucederle otro Ministro no menos ambicioso [Luis Méndez de Haro y Guzmán, II Conde Duque de Olivares (1598$1661)^{72}$, sobrino del primer Conde Duque de Olivares]". ${ }^{73}$ Precisamente, durante el ejercicio de sus funciones se sofocó la revuelta catalana, reconquistándose Barcelona para la Monarquía Hispánica (1652). Asimismo, Luis Méndez de Haro y Guzmán fue el principal negociador español del Tratado de los Pirineos rubricado el 7 de noviembre de 1659 que sin contar con el beneplácito de las Cortes catalanas supuso la separación del Principado de Cataluña del Rosellón, Conflent, Vallespir, Capcir y una parte del condado de Cerdaña. En palabras del eclesiástico José Espiga y Gadea Luis de Haro manipuló el Consejo de Estado a través de una reducida Junta de Estado que se reunía en su residencia privada, ya que debido a su carácter discreto prefería actuar en la sombra. A su muerte se reactivó el Consejo de Estado y, por tanto, los Secretarios de Estado recuperaron buena parte de su protagonismo originario, como de hecho convenía a un gobierno sin la figura de un valido. ${ }^{74}$ Así pues, de la alocución de la dignidad de

67 Joan Lluís Palos, “¿El Estado contra Cataluña? Estrategias de control y limitaciones del poder real en los siglos XVI-XVII”, Manuscrits, n 13, 1995, pp. 143-154.

68 John H. Elliott, La revolta catalana (1598-1640). Un estudi sobre la decadència d'Espanya, Valencia, Publicaciones de la Universidad de Valencia, 2006, p. 381.

69 Consultar Antoni Simon i Tarrés, Pau Claris, líder d'una classe revolucionària, Barcelona, Publicacions de 1'Abadia de Montserrat, 2008.

70 Francesc Martí i Viladamor, Les Corts Generals de Pau Claris, edición a cargo de Basilio de Rubí, Barcelona, Fundació Salvador Vives Casajuana, 1976, p. 253.

71 DSC, núm. 378, 15 de octubre de 1811, p. 2085.

72 Véase Lynn Williams, "Jornada de D. Luis Méndez de Haro y Guzmán a Extremadura, 16581659: implicaciones para la politica internacional española del momento”, Manuscrits, n ${ }^{\circ} 31,2013$, pp. 115-136; Andrés Gambra, “Don Luis Méndez de Haro, el valido encubierto”, en José Antonio Escudero López (edit.), Los validos, Madrid, Dykinson, 2004, pp. 277-310; y Rafael Valladares (edit.), El mundo de un valido. Don Luis de Haro y su entorno, 1643-1661, Madrid, Marcial Pons, 2016.

73 DSC, núm. 629, 10 de agosto de 1812, p. 3522.

74 Consultar Cristina Hermosa Espeso, "Ministros y ministerio de Felipe IV (1661-1665). Una aproximación a su estudio”, Investigaciones Históricas, n² 27, 2007, pp. 47-76. 
la catedral de Lérida se desprende un interesante vínculo entre la pérdida de influencia del Consejo de Estado, la intensificación del absolutismo regio y el intento de atenuar o incluso anular las constituciones, leyes y privilegios catalanes.

\section{III.- LA CRÍTICA AL ABSOLUTISMO DE LOS BORBONES}

Las Cortes celebradas en Barcelona por Felipe V durante los años 17011702 revitalizaron el régimen pactista catalán. ${ }^{75}$ De la misma forma, las constituciones y los capítulos aprobados en las Cortes catalanas de 1705-1706 presididas por el Archiduque Carlos de Habsburgo reforzaron las libertades de los catalanes tanto por la consolidación de los mecanismos de representación política como por la aplicación de medidas encaminadas a vigilar las decisiones adoptadas por el rey y, sobre todo, controlar la actuación de los ministros y los oficiales reales para así poder perseverar el cumplimiento de la ley. ${ }^{76}$ Tal y como se puso de manifiesto en la Exposición de los señores diputados de Cataluña en la sesión del 4 de enero de $1813^{77}$ que dirigieron a las Cortes de Cádiz los parlamentarios catalanes partidarios de mantener el Tribunal del Santo Oficio: "Examínese las últimas Cortes celebradas en Barcelona por Carlos, que era el tercero, en 1706, en tiempo que gozaban los catalanes de la plenitud de su libertad y derechos; tiempo en que la rivalidad y competencia de los dos aspirantes a la corona aumentaban en algún modo el espíritu de que naturalmente por sus usos y costumbres estaban ellos dotados, para pedir cuanto estimasen útil a sus libertades y fueros". ${ }^{78}$

De este modo, en el Congreso gaditano las últimas Cortes catalanas sirvieron de ejemplo para poder evocar una tradición constitucional que debido a su carácter contractual atesoraba las suficientes garantías para contrarrestar con éxito el avieso despotismo regio y ministerial, eso sí, hasta la caída de Barcelona (11 de septiembre de 1714), ya que la victoria militar de las tropas borbónicas en la Guerra de Sucesión permitió a Felipe V instaurar un modelo de Estado absolutista y autoritario revestido de un acentuado centralismo político y

75 En dicho sentido Melchor Rafael de Macanaz dejó escrito en sus Memorias para la Historia que "lo cierto es que por sus repetidas rebeliones, por gracias sacadas por fuerza de los señores reyes de la Casa de Austria y, últimamente, por las de Su Majestad [Felipe V], [los catalanes] llegaron a verse tan absolutos como las repúblicas de Venecia y Holanda, su Parlamento más soberano que el de Inglaterra y Su Majestad con menor autoridad que la del menor catalán". Eduardo Lama Romero, Macanaz Memorialista. Una aproximación a la formación del Estado borbónico, Córdoba, Universidad de Córdoba, 2009, p. 50.

76 Joaquim Albareda i Salvadó, “Encara sobre l'austriacisme”, Pedralbes, n 23, 2003, pp. 192 y 206; y Constitucions, Capitols i Actes de Cort. Anys 1701-1702 i 1705-1706, estudio introductorio a cargo de Joaquim Albareda, edición facsímil, Barcelona, Editorial Base, 2004, pp. 5-33.

77 Firmada por Jaime Creus, Ramón Lázaro de Dou, Francisco Morrós, Félix Aytés, Juan de Suelves, Ramón de Lladós, Juan Bautista Serres, Francisco de Papiol, Juan de Balle, José Vega y Francisco Calvet.

78 Lluís Ferran Toledano González, "Historicisme i politica de la classe dirigent catalana en el debat constitucional gadità”, en Agustí Alcoberro y Giovanni Cattini (edit.), Entre la construcció nacional i la repressió identitària, Actes de la Primera Trobada Galeusca d'Historiadores $i$ d'Historiadors, Barcelona, Generalitat de Catalunya, 2012, pp. 211-212; y Jordi Roca Vernet, “Las Cortes de Cádiz. Génesis del liberalismo romántico catalán”, Trienio: ilustración y liberalismo, $\mathrm{n}^{\circ}$ 61,2013, p. 101. 
uniformismo administrativo. Por justo derecho de conquista el Decreto de Nueva Planta de 16 de enero de 1716 derogó las principales instituciones del Principado catalán, como las Cortes, la Diputación del General ${ }^{79}$ o Generalidad -organismo encargado de velar por el cumplimiento de las Constitucions $i$ altres drets de Catalunya- y el régimen municipal, de carácter electivo, en especial, el Consejo de Ciento barcelonés ${ }^{80}$. De esta manera, en Cataluña el derecho público quedó básicamente sustituido por el de Castilla. ${ }^{81}$ Además, la Nueva Planta permitió al monarca establecer nuevos tributos sin la necesidad, como antaño, de contar con el consentimiento de las Cortes catalanas, pudiendo así imponer agravios fiscales como el Real Catastro ${ }^{82}$, un nuevo gravamen directo que incrementó de manera significativa la presión impositiva, tal y como denunció en las Cortes de Cádiz el diputado catalán Ramón Lázaro de Dou al aseverar que "con demostración matemática se puede hacer ver que en todo el siglo XVIII ha pagado Cataluña más que Castilla". 83

Únicamente, a partir de la experiencia previa atesorada por la aplicación práctica de los Decretos de Nueva Planta de Valencia y Aragón y, manifiestamente, de acuerdo al criterio del miembro del Consejo de Castilla Francisco Ametller i Perer ${ }^{84}$, jurista y político catalán felipista encargado de elaborar la ponencia del Decreto de Nueva Planta conjuntamente con José Patiño y Rosales, presidente de la Junta Superior de Justicia y Gobierno del Principado, se mantuvo en Cataluña el derecho privado, por tanto, particular, o sea, el civil, el penal, diversos aspectos del procesal, en concreto, los estilos y la práctica judicial ${ }^{85}$, el mercantil y el supletorio del civil -canónigo y romano-86. Así pues,

79 En atención a que el histórico señorío de Molina obtuviera el rango de provincia el diputado José Roa declaró que "aun en el día mantiene su diputación como antes, a pesar de haberse suprimido en los [territorios] de la Corona de Aragón por los esfuerzos del despotismo ministerial en el siglo pasado y estos últimos años". DSC, núm. 335, 2 de septiembre de 1811, p. 1742.

80 Capmany puso de manifiesto que "en esta forma popular continuaron en Cataluña hasta principios del siglo XVIII los ayuntamientos de todas las ciudades y villas, siendo su modelo Barcelona, capital y ciudad insigne y corte de los Reyes de Aragón, en medio de una Monarquía (pero templada por leyes constitucionales), hasta que las armas de Felipe V las hicieron callar... y Barcelona recibió un nuevo ayuntamiento bajo la planta aristocrática de las demás ciudades de la Corona de Castilla”. DSC, núm. 629, 10 de agosto de 1812, pp. 3521-3522.

81 Consultar Sebastià Solé i Cot, El gobierno del principado de Cataluña por el Capitán General y la Real Audiencia -el Real Acuerdo- bajo el régimen de nueva planta (1716-1808): una aportación al estudio del procedimiento gubernativo a finales del Antiguo Régimen, Barcelona, Universidad Pompeu Fabra, 2008; y Carlos Antonio Garriga Acosta, "Sobre el gobierno de Cataluña bajo el régimen de la Nueva Planta. Ensayo historiográfico", Anuario de Historia del Derecho Español, ${ }^{\circ}$ LXXX, 2010, pp. 715-765.

82 Véase Agustí Alcoberro i Pericay, "El cadastre de Catalunya (1713-1845): de la imposició a la fossilització”, Pedralbes, n $^{\circ} 25,2005$, pp. 231-257.

83 DSC, núm. 916, 19 de julio de 1813, p. 5749.

84 Consultar Gemma García Fuertes, "Francesc Ametller i Perer (1657/8-1726). Un jurista català al servei de Felip V”, Pedralbes, n 28, 2008, pp. 165-202.

85 Carlos Antonio Garriga Acosta, "Despotismo ilustrado y desorden social: la restauración de la Nueva Planta de la Audiencia de Cataluña (1775)", Initium: Revista catalana d'història del dret, $\mathrm{n}^{\circ}$ 2, 1997, p. 485.

86 Josep Maria Gay Escoda, "Notas sobre el derecho supletorio en Cataluña desde el decreto de Nueva Planta (1715) hasta la jurisprudencia del Tribunal Supremo (1845)", en Bartolomé Clavero, Paolo Grossi y Francisco Tomás y Valiente (dirs.): Hispania. Entre derechos propios y derechos 
no todo el ordenamiento jurídico fue abolido, hasta el punto que fue necesario conocer las constituciones, leyes y privilegios catalanes y la obra de los principales juristas del siglo XVI, XVII y XVIII, contribuyendo a la preservación del legado constitucional catalán 87 , eso sí, en buena medida porque las autoridades borbónicas temieron el desbarajuste social y económico que se podía desatar si lo anulaban, siendo más útil y conveniente quedarse en unos determinados "términos medios". 88 Por ejemplo, en el Congreso gaditano el canciller de la Universidad de Cervera Ramón Lázaro de Dou efectuó un vehemente alegato a favor de la conservación del derecho privado catalán, precisamente, a partir del "ejemplo que nos dio el Sr. D. Felipe V en Cataluña, y en algunas otras provincias [Valencia, Aragón y Mallorca] (...). Cuando se terminó la Guerra de Sucesión, se dudó mucho en Cataluña sobre variar del todo el sistema de la legislación: prevaleció la opinión contraria, derogándose solamente algunas leyes, estableciéndose otras, y renovándose la observancia de las más útiles. Así se hizo una obra grande, esto es, la nueva planta de Gobierno, que consiste en uno o dos pliegos, y forma uno de los autos acordados". 89

Debido a su significativa transcendencia histórica el diputado asturiano Agustín de Argüelles se dispuso a analizar el proceso de elaboración de la Nueva Planta borbónica:

"Cuando Felipe V hizo en este asunto, por lo que toca a Cataluña, las alteraciones
que son bien notorias, no se tacharon de atropelladas [septiembre de 1714 - enero de
1716 ; y eso que los bandos y parcialidades que habian seguido la causa de su
contendedor parece que le debian haber obligado a respetar unos privilegios que

nacionales. Per la storia del pensiero giuridico moderno, Milán, Giuffré Editore, Vol. II, 1990, pp. 805-865; y Juan Berchmans Vallet de Goytosolo, "El Dret romà a Catalunya després del decret de Nova Planta", Revista de Dret Històric Català, nº 7, 2007, pp. 161-166.

87 El Decreto de Nueva Planta ordenó conservar el derecho público catalán en diversos artículos: "los relatores han de ser prácticos y expertos en los negocios de Cataluña, para poder comprender, bien los procesos y escrituras antiguas (Art. 8); "se impondrán penas, y se estimarán las probanzas, según las Constituciones, y práctica, que havia antes en Cataluña (Art. 28); y, sobre todo, "en todo lo demás, que no está prevenido en los Capítulos antecedentes de este Decreto, mando se observen las Constituciones que antes havia en Cataluña (Art. 56). Jordi Günzberg Moll, "Instituciones públicas catalanas después del real decreto de Nueva Planta", Ivs Fvgit, $\mathrm{n}^{\circ}$ 13-14, 2004-2005, p. 272.

88 Josep Maria Gay Escoda, "La gènesi del Decret de Nova Planta de Catalunya. Edició de la consulta original del Consejo de Castilla de 13 de juny de 1715", Revista Jurídica de Catalunya, $\mathrm{n}^{\circ}$ LXXXI-1, 1982, pp. 7-41 y n ${ }^{\circ}$ LXXXI-2, pp. 261-348; y Jon Arrieta, "Catalunya entre els segles XVII i XVIII. Reflexions sobre un canvi”, Revista de Dret Històric Català, n ${ }^{\circ}$ 7, 2007, pp. 104-110.

89 DSC, núm. 132, 5 de febrero de 1811, p. 502. Asimismo, el discurso del diputado catalán Ramón Lázaro de Dou nos muestra como el régimen borbónico había establecido en el Principado unas densas redes clientelares legitimadoras de su obra y su gobierno. De hecho, precisamente por haber sido el autor del Decreto de Nueva Planta, Dou llegó a encumbrar la figura de Felipe V hasta el extremo de llamarle "el Solón de Cataluña", de acuerdo a los gustos estéticos del siglo XVIII, ya que el neoclasicismo supone la admiración decidida del ideario griego. En concreto, éstas son las palabras exactas que Dou pronunció en su discurso de 19-XII-1783 en la Universidad de Cervera: "Voy a demostrar hoy que Felipe V fue el Solón de Cataluña, el legislador más sabio y prudente de esta provincia”. Véase Ricardo García Cárcel, De los elogios a Felipe V, Madrid, Centro de Estudios Políticos y Constitucionales, 2002, pp. 131 y ss. Eso sí, según su biógrafo Guillermo María de Brocà y de Montagut "ese tipo de actuaciones académicas eran costumbre por miedo al poder del Estado". Joaquim Prats, "Historiografia y publicismo sobre la Universidad de Cervera: Entre el mito y el sambenito", Manuscrits, n 6, 1987, p. 58. 
existían en su país, y que por lo mismo no eran desconocidos. Sin embargo, aquellas novedades no se hicieron en Cortes, pues ya tuvo buen cuidado de seguir el consejo de su astuto abuelo Luis XIV que entre otras instrucciones le dijo: < No derogues las Cortes en España, pero no las convoques jamás>”. ${ }^{90}$

De la intervención de Argüelles se puede corroborar que el nuevo corpus normativo se elaboró con sosiego, por tanto, responde a unas disposiciones bien meditadas. Del mismo modo, el jurista asturiano remarcó el carácter civil de la contienda bélica y, por ello, destacó el hecho que Felipe V suprimió el modelo politico pactista de manera unilateral, sin contar ni tan solo con el parecer de los catalanes prosélitos del bando borbónico ${ }^{11}$ partidarios de preservar las constituciones, leyes y privilegios catalanes. Por último, el Divino hizo hincapié en el signo absolutista del gobierno felipista, legitimado en el derecho de conquista para establecer un nuevo régimen politico sin la necesidad de requerir su aprobación por parte de las Cortes, llamadas a ocupar un lugar irrelevante, de acuerdo al consejo de su abuelo, Luís XIV92, le Roi Soleil, conocido por la célebre declaración programática "l'Etat, c'est moi", o sea, "el Estado soy yo".93

Así pues, por la fuerza de las armas se puso fin a la tradición constitucional pactista fundamentada en la soberanía compartida entre el rey y las Cortes catalanas. La soberanía real de derecho divino impuesta por la dinastía francesa legitimó por sí sola la concentración de todos los poderes en manos del monarca sin que ninguna carta magna o institución pudiera cuestionar su actuación política. El soberano constituía la encarnación misma del Estado, dado que era fuente de ley, autoridad máxima del gobierno y juez supremo. De este modo, la Monarquía Hispánica se convirtió en un dominio directo del rey. En dicho sentido, en el Congreso gaditano el diputado catalán Ramón Lázaro de Dou evidenció que "los Reyes de España, siendo así que no solo ejercian la soberanía que comprende el Poder ejecutivo, sino también la que incluye el legislativo y judiciario, promulgaban las leyes". 94

Asimismo, la supresión del Consejo Supremo de Aragón, tal y como puso de manifiesto el historiador Antonio de Capmany al aseverar que "desde los Reyes Católicos había en la corte otro Consejo Real, que era el Supremo de Aragón (...).

90 DSC, núm. 248, 6 de junio de 1811, p. 1199.

91 Los conocidos despectivamente con el apelativo de botiflers por ser considerados traidores. Véase Núria Sales, Els botiflers, 1705-1714, Barcelona, Rafael Dalmau Editor, 1981. En este sentido, cabe destacar que una enorme cantidad de opúsculos escritos por catalanes partidarios del bando felipista apoyaron a la dinastía borbónica con argumentos como la benignidad de Felipe V y, especialmente, la seguridad que los privilegios que estaba defendiendo la causa del Emperador austríaco solamente beneficiaban a los grupos sociales más poderosos. Carlos Pizarro Carrasco, (1998): "El discurso de la resistencia a través de El Despertador de Catalunya (1713)", Pedralbes, $\mathrm{n}^{\circ} 18,1998$, p. 347.

92 Luís XIV atesoró una dilatada práctica en el arte de dar consejos. En sus memorias, destinadas a ayudar y guiar a su hijo primogénito en la ardua labor de reinar, el Rey Sol dejó un interesante testimonio de sus ideas e intereses. Al respecto, consultar LUÍS XIV, Memorias sobre el arte de gobernar, Buenos Aires, Espasa-Calpe, 1947.

93 A pesar de que Luís XIV nunca pronunció "el Estado soy yo" que le atribuye la leyenda. Josep Fontana, "La Guerra de Successió: els motius de Catalunya", Revista de Dret Històric Català, $\mathrm{n}^{\circ} 3,2004$, p. 17.

${ }_{94}$ DSC, núm. 370, 7 de octubre de 1811, p. 2009. 
Pero después que Felipe V extinguió este último, incorporándole al de Castilla"95, incrementó la acción del Consejo de Castilla, adquiriendo facultades legislativas, administrativas y judiciales durante el XVIII ${ }^{96}$, centuria conocida como el siglo del absolutismo regio, bien caracterizado por el enunciado el rey con los ministros que substituyó el fundamento de la política de los Austrias: los grandes con el rey. ${ }^{97}$ Ciertamente, los Borbones consolidaron un modelo más gobernativo o ejecutivo en detrimento del deliberativo de los Habsburgo. El ministro Orry y la princesa de los Ursinos promovieron la fórmula un rey que gobierna por sí solo ${ }^{98}$, únicamente aconsejado por su gabinete. De esta forma, Felipe $\mathrm{V}$ pudo gobernar de una manera autocrática, máxime cuando, de acuerdo a las instrucciones precisas que Luis XIV hizo llegar a su nieto desde la corte de Versalles menospreciando el gobierno a través de los Consejos ${ }^{99}$, instituyó un Consejo de Gabinete o de Despacho (1702), compuesto por personas de su confianza, escogidas mediante la simple voluntad real e inmediatamente cesantes a petición suya, que proporcionaban al rey las informaciones necesarias para tomar una adecuada decisión, hasta el punto que para aumentar su capacidad se añadió una secretaría, equivalente a la Secretaría del Despacho Universal, dividida en dos Guerra y Hacienda- (1703) ${ }^{100}$; y, poco después de la caída de Barcelona, el primer soberano de la dinastía borbónica potenció la posición de los secretarios del Despacho frente a los consejeros de Estado mediante el Real Decreto de 30 de noviembre de $1714 .{ }^{101}$

Al respecto, en palabras del parlamentario catalán Antonio de Capmany: "ya fuese la autoridad o la sabiduria, o bien el nombre respetable de este senado [Consejo de Estado], habria hecho en algún tiempo sombra a la corte de Francia, pues que, entre las instrucciones secretas que recibió Felipe $\mathrm{V}$ del gabinete de Versalles, acabada la guerra de Sucesión, se cuenta la de no juntar más dicho Consejo, que virtualmente fue extinguido en su ejercicio, y la de no convocar Cortes, cuyo solo nombre incomodaba al Gobierno francés". 102 Por ende, una vez

95 DSC, núm. 86, 21 de diciembre de 1810, p. 205.

96 "El Consejo aprueba siempre lo que el Rey le somete". Concepción De Castro, "El Estado español en el siglo XVIII: su configuración durante los primeros años del reinado de Felipe V", Historia y politica, $\mathrm{n}^{\circ} 4,2000$, pp. 138 y 157.

97 José Luis Gómez Urdáñez, “El absolutismo regio en España durante la Ilustración”, Brocar, $\mathrm{n}^{\circ}$ 26, 2002, p. 157.

98 Anne Dubet, Un estadista francés en la España de los Borbones. Juan Orry y las primeras reformas de Felipe V (1701-1706), Madrid, Editorial Biblioteca Nueva, 2008, p. 306.

99 Luís XIV aconsejó a Felipe de Anjou actuar como un monarca absoluto de origen divino: "No os dejéis gobernar, sed el amo. No tengáis nunca favorito ni primer ministro. Oíd y consultad a vuestro Consejo, pero reservad la resolución. Dios, que os ha hecho rey, os dará los auxilios necesarios con tal que sea buena la intención". Concepción De Castro, "El Estado español en el siglo XVIII: su configuración durante los primeros años del reinado de Felipe V”, op. cit., p. 141.

100 Jean-Pierre Dedieu, "La Nueva Planta en su contexto. Las reformas del aparato del Estado en el reinado de Felipe V”, Manuscrits, n 18, 2000, pp. 114-116.

101 Las dos Secretarias del Despacho se desdoblaron en cinco oficinas independientes: Estado; Hacienda; Justicia; Guerra y Marina; e Indias. María Victoria López-Cordón, "Instauración dinástica y reformismo administrativo: la implantación del sistema ministerial”, Manuscrits, $\mathrm{n}^{\circ} 18$, 2000, p. 98.

102 DSC, núm. 378, 15 de octubre de 1811, p. 2084. En la Consulta al País Antonio de Capmany ya habia certificado la existencia de un "Consejo sólo de nombre y enteramente muerto 
que Felipe $\mathrm{V}$ se impuso militarmente derogó cualquier vestigio de la estructura político-administrativa de los Austrias que pudiera significar una limitación del poder real para así poder imponer el régimen absolutista vigente en el Reino de Francia desde el siglo XVII, precisamente, desde donde se urdió la nulidad del Consejo de Estado y se desaconsejaron las sucesivas convocatorias de Cortes, más si cabe cuando eran los únicos contrapoderes capaces de evitar la arbitrariedad regia. De esta forma, Capmany explicitó en las Cortes de Cádiz como la victoria militar de las tropas borbónicas supuso la imposición de un sistema absolutista a imitación del modelo politico-institucional francés $\mathrm{y}$, especialmente, la subordinación de la Monarquía Hispánica a los designios de Versalles.

Efectivamente, el Consejo de Estado, institución fundamental y efectivo órgano consultivo del gobierno hasta la muerte de Carlos II $^{103}$, pasó a ser considerado un mero instrumento decorativo que únicamente servía para ratificar las decisiones más relevantes tomadas de antemano por el monarca borbónico de forma privativa. Sin embargo, Felipe V, conocido como el Animoso, paulatinamente se convirtió en un rey consorte de la reina Isabel de Farnesio. A la sazón, sin la menor oposición, el cardenal Giulio Alberoni, en calidad de consejero personal del monarca, asumió el control directo de prácticamente la totalidad de los negocios públicos. El eclesiástico italiano, como único depositario de la confianza real, adquirió una imponente autoridad y, fruto de su poder poco más o menos que absoluto, ejerció su cargo de forma despótica. De acuerdo al testimonio de José Espiga y Gadea "el cardenal Alberoni, aprovechándose de las circunstancias de la Europa y del influjo que tenía en los Gabinetes, redujo el Consejo a una completa nulidad, suspendiendo sus sesiones". ${ }^{104}$ De este modo, según el parlamentario catalán, una vez finalizada la Guerra de Sucesión, el Consejo de Estado "encontró un poderoso enemigo en el genio activo y orgulloso del cardenal Alberoni [1715-1719]". Efectivamente, la conocida como vía reservada se erigió en un sistema ordinario para el despacho a boca de los

desde que por una de las instrucciones secretas de la Corte de Versalles le dejó sin uso Felipe V". Así como "la tiranía de los últimos ministerios [Floridablanca y Godoy]". BN, Ms. 20.260/4. Sevilla, 17 de octubre de 1809. Miguel Artola, Los origenes de la España contemporánea, op. cit., Vol. II, p. 452.

103 Tal y como acreditó el diputado catalán Antonio de Capmany cuando, en relación a la quinta facultad del monarca doceañista, hizo saber que desde el reinado de "Carlos I hasta la entrada de Felipe V, el Consejo de Estado, al cual se unió después el de Guerra, proponía al Rey los empleos superiores, como virreinatos, gobiernos militares y políticos, capitanias generales, gobiernos de provincia: todos estos destinos eran de consulta del Consejo de Estado, con la cual se conformaba el Soberano, o no se conformaba”. DSC, núm. 378, 15 de octubre de 1811 , p. 2084. En dicho sentido, el Artículo 237 sancionó que "Pertenecerá a este Consejo hacer al Rey la propuesta por ternas para la presentación de todos los beneficios eclesiásticos, y para la provisión de las plazas de judicatura". Constitución politica de la Monarquía española. Promulgada en Cádiz a 19 de marzo de 1812, op. cit., p. 37. De esta forma, en palabras de Francisco Tomás y Valiente, "el Rey tiene la decisión, pero el Consejo tiene la llave: la terna. Quien propone, limita y en último término dispone, puesto que excluye, eliminando a quienes considere "non gratos". No se olvide que el Consejo, aun siendo nominalmente "del Rey", es obra de las Cortes, autoras de la terna para cada vacante, y que el Rey no podia deponer a sus consejeros, pues el art. 239 disponia que los consejeros no podrian "ser removidos sin causa justificada ante el Tribunal Supremo de Justicia", un Tribunal cuyos miembros debían su condición de magistrados a la libre propuesta del propio Consejo". "El Consejo de Estado en la Constitución de 1812", op. cit., p. 14.

104 DSC, núm. 457, 3 de enero de 1812, p. 2540. 
asuntos de Estado que habían sido arrebatados al Consejo, contribuyendo, de esta forma, a la centralización del aparato politico-administrativo de la monarquía y, por consiguiente, al fortalecimiento de la autoridad real. A partir de aquel momento, tal y como expuso la dignidad de la catedral de Lérida exclusivamente cinco Secretarios de Estado y del Despacho "despacharon en adelante privadamente con el Rey todos los asuntos que antes se examinaban, consultaban y decidian en el Consejo, y las deliberaciones que hasta aquí habían sido el resultado de la experiencia y sabiduria de los hombres más dignos de la Nación, fueron después el efecto necesario de las sugestiones misteriosas de los Ministros". 105

De forma taxativa, en un alegato a favor del mérito y la valía, el diputado representante de la Junta Superior de Cataluña reivindicó la tradición institucional forjada en el medievo por ser capaz de albergar las luces de los más insignes prohombres $\mathrm{y}$, substancialmente, por impedir el favoritismo, la opacidad, la corrupción y la arbitrariedad propia del despotismo ministerial característico del absolutismo regio. De esta manera, en opinión de José Espiga el Consejo de Estado se había de constituir en un cuerpo constitucional106: "No dude V. M. [las Cortes de Cádiz] un instante de su establecimiento: él solo [se entiende, el Consejo de Estado] podrá ilustrar a los Reyes para que no sean jamás sorprendidos por la aducción de los privados, y él solo podrá descubrir los caminos tortuosos por donde se les hace marchar hasta llegar a la ruina de la Nación". 107

Así que, el despotismo ministerial, iniciado bajo el reinado de los Austrias Menores, fue heredado e inclusive impulsado por la nueva dinastía borbónica, en buena medida, según el criterio del eclesiástico José Espiga y Gadea porque "si era natural que faltando la causa que producía estos efectos violentos volviera el Gobierno a tomar su curso ordenado y regular, no lo era menos que, no

105 DSC, núm. 390, 27 de octubre de 1811, p. 2160.

106 "El Consejo de Estado es el único Consejo del Rey, que oirá su dictamen en los asuntos graves gubernativos, y señaladamente para dar o negar la sanción a las leyes, declarar la guerra, y hacer los tratados". Constitución política de la Monarquía española. Promulgada en Cádiz a 19 de marzo de 1812, op. cit., p. 37. Tal y como abogó en sede parlamentaria el integrante de la comisión constitucional José Espiga: "La sanción de las leyes, la declaración de la guerra, la ratificación de la paz, la dirección de la fuerza armada, el orden y tranquilidad pública y la defensa exterior, en una palabra la suerte de la Nación ¿ise pondrá en manos de un Rey de quien si se debe esperar bondad, nobleza y generosidad y buenos deseos, no se puede asegurar ni todos los conocimientos necesarios para el acierto, ni toda la experiencia contra la seducción? Lejos de nosotros esta conducta impolítica que conduciría a unos extravíos funestos. En vano V.M. habrá sancionado todo lo que hasta aqui ha merecido la aprobación del Congreso y lo que está para presentarse a discusión, si V.M. no aprueba esta parte tan interesante de la Constitución. La comisión ha creído indispensable establecer cerca del Rey un cuerpo que no sólo ilustre la dificultad, complicación y oscuridad de los negocios, sino que contenga la arbitrariedad y haga inútiles todos los esfuerzos de los linsojeros que por desgracia rodean siempre el Trono". DSC, núm. 390, 27 de octubre de 1811, p. 1159. De este modo, el Consejo de Estado se instituyó con el objetivo de garantizar que las principales facultades regias nunca fueran ejercidas mediante la imposición arbitraria del monarca. De acuerdo al criterio de Francisco Tomás y Valiente el Consejo de Estado "es una pieza politica en el equilibrio entre poderes. Una pieza original, a mitad de camino entre Senado, Diputación de las Cortes, consejo de gobierno o mecanismo de vigilancia del Rey". "El Consejo de Estado en la Constitución de 1812", op. cit., p. 21.

107 DSC, núm. 390, 27 de octubre de 1811, p. 2161. 
habiendo, una Constitución que enfrenase el poder ministerial, ocupasen este destino unos dignos sucesores de los Ministros de los Felipes IV y V, y que imitasen estos ejemplos, que tanto lisonjean el corazón humano". ${ }^{108}$ En un discurso eminentemente constitucionalista el parlamentario catalán vindicó la carta magna doceañista como garantía de la preservación de la separación de poderes, fundamentalmente con el objetivo de imposibilitar que las decisiones más significativas se tomaran en un círculo cerrado de familiares, confidentes y amigos personales del monarca, tal y como tuvo lugar en tiempos de Giulio Alberoni, quién, pese a sus orígenes humildes, pudo iniciar su carrera politica como secretario de Louis Joseph, duque de Vendôme, comandante en jefe de las tropas hispano-francesas en Italia en el decurso de la Guerra de Sucesión. Justamente, durante las estancias del general en Versalles el eclesiástico pudo conocer a Luís XIV y a los principales integrantes de la Corte francesa. Posteriormente, Alberoni sirvió al duque de Parma, desde donde dirigió las negociaciones entre el duque italiano y Felipe $\mathrm{V}$ que posibilitaron el matrimonio del nuevo monarca español en segundas nupcias con Isabel de Farnesio, sobrina del duque parmesano, en el año 1714. El favor de la nueva reina por haber facilitado el acceso al trono permitió a Giulio Alberoni beneficiarse del nepotismo borbónico, obteniendo cuantiosas rentas, honores y oficios, por ejemplo, la administración del arzobispado de Tarragona, el título de Grande de España, el cargo de consejero del rey (1715-1719) y el obispado de Málaga, llegando incluso a ser nombrado cardenal. 109

Especial mención, por la ausencia de contrapoderes destinados a frenar el despotismo ministerial, según el parecer de José Espiga y Gadea, merece la última parte del reinado de Carlos III $^{110}$, a pesar del reformismo borbónico característico de la época del Despotismo Ilustrado ${ }^{11}$, una vez más, por permitir el ocaso del Consejo de Estado:

"el Conde de Floridablanca (cuya memoria, si bien es recomendable por sus luces, conocimientos y política, no es menos reprensible por su ambición y deseo de mandar en todos los ramos del gobierno) no se contentó, habiendo ganado el corazón de Carlos III, componer unos Ministros que suscribiesen a todos sus proyectos, sino que trató de sofocar el Consejo de Estado cuya autoridad embarazaba tanto su arbitrariedad, y al mismo tiempo dictar las resoluciones correspondientes a todas las Secretarias. No le fue dificil conseguir uno y otro, y sorprendiendo el ánimo del Rey, sobre el que tenía tanto imperio, arrancó el decreto, por el que se creó una junta compuesta de todos los Ministros, que hubiera de entender en todos los negocios graves del Estado. Desde entonces ya no se consultó al Consejo de Estado; este no se volvió a juntar, y fue sepultado en un vergonzoso silencio, mientras que presentándose como un oráculo el

108 DSC, núm. 457, 3 de enero de 1812, p. 2540.

109 Enormemente ambicioso, según el marqués de San Felipe "Alberoni no servía más que a sí mismo". Véase Isabel Martínez Navas, "Alberoni y el gobierno de la Monarquía española”, REDUR, $\mathrm{n}^{\circ}$ 8, 2010, pp. 63-110; y Maximiliano Barrio Gozalo, "El cardenal Alberoni y España. Politica religiosa y carrera eclesiàstica”, Hispania Sacra, Vol. LXIII, n 127, 2011, pp. 205-234.

110 Tercer vástago de Felipe V, primogénito de los siete hijos que tuvo con Isabel de Farnesio. Véase Roberto Fernández Díaz, Carlos III, Madrid, Arlanza ediciones, 2001; Antonio Domínguez Ortiz, Carlos III y la España de la Ilustración, Madrid, Alianza Editorial, 2005; y Vicente Palacio Atard, Carlos III: el rey de los ilustrados, Barcelona, Ariel, 2006.

111 De acuerdo al criterio de Günter Barudio: "Ilustración y absolutismo se excluían mutuamente" y "el monarca más ilustrado seguía siendo un soberano absoluto". La época del absolutismo y la Mustración. 1648-1779, Madrid, Siglo XXI, 1992, p. 362. 
Conde de Floridablanca en la junta de Ministros, dictaba todas las providencias, y haciéndose oír como un órgano de la voluntad del Rey, nadie se atrevía a oponerse a su dictamen". ${ }^{112}$

En el decurso del proceso constituyente gaditano el parlamentario catalán José Espiga criticó con contundencia la figura de José Moñino Redondo (17281808), más conocido como I conde de Floridablanca (1773), el personaje más representativo del absolutismo ilustrado español, porque, al margen de su incuestionable valía personal, como principal recurso y mérito recurrió a su amistad con Carlos III para ser nombrado secretario del Despacho de Estado (1777), como paso previo y necesario para imponer su voluntad, máxime al rodearse de unos ministros sumisos a sus dictámenes que sin oposición alguna le permitieron reemplazar el Consejo de Estado por una Junta de Estado dispuesta a su más estricto servicio, principalmente cuando el Consejo de Estado era el único órgano capacitado para limitar las veleidades del ejecutivo al poder consensuar y acordar, de manera colegiada, las resoluciones más convenientes para los intereses del conjunto de la Monarquía Hispánica.

De hecho, los cerca de treinta años del reinado de Carlos III (1759-1788), pese a su incuestionable espiritu reformista, sirvieron para consolidar el autoritarismo monárquico en un mayor grado, eliminando los obstáculos que pudieran restringir el poder absoluto del monarca, sacralizando su figura hasta el punto de considerarse una autoridad suprema inapelable. Ciertamente, el Despotismo Ilustrado se convirtió en una forma eficaz de modernización del absolutismo. El rey mandaba y, como mucho, sus ministros administraban: $E l$ rey lo daba todo y lo quitaba todo. ${ }^{113} \mathrm{El}$ antiguo Consejo de Estado se vació de contenido, traspasándose la mayor parte de sus atribuciones al Consejo de Castilla. Precisamente, el primer cargo que asumió Floridablanca fue el de fiscal de la sala criminal del Consejo de Castilla (1766), desde donde comenzó a tejer una densa red clientelar hasta obtener el puesto de principal ministro (1777). Mediante el Real Decreto de 8 de julio de 1787 Moñino instituyó la citada Junta de Estado ${ }^{114}$, en principio, destinada a coordinar la acción política de las diferentes secretarias en una especie de Consejo de Ministros con la finalidad de evitar el aislamiento ministerial y los conflictos entre los diversos ámbitos de la administración borbónica, no obstante, de facto, representó la reducción a la minima expresión del sistema de consejos, limitados exclusivamente a las cuestiones de justicia, por tanto, a la postre, supuso un significativo aumento del poder de Floridablanca hasta ultrapasar la autoridad de Carlos III, ya que, la Junta de Estado, presidida por el mismo José Moñino, controló de manera exclusiva y por delegación la potestad ejecutiva, pasándose, de esta manera, de un monarca déspota a un ministro déspota. El ingente poderío y la elevada consideración social permitieron al conde de Floridablanca continuar en su cargo de universal ministro una vez que accedió al trono Carlos IV (1788), incluso en el año 1791 recibió el Toisón de Oro. Eso sí, como en última instancia la figura del secretario dependía por completo del rey, quién podía cesarlo en cualquier

112 DSC, núm. 457, 3 de enero de 1812, p. 2541.

113 José Luis Gómez Urdáñez, "Ideas políticas y agentes del triunfo del Despotismo Ilustrado Español (1756-66)", Revista Història Moderna i Contemporània, nº X, 2012, pp. 53-54.

114 Consultar José Antonio Escudero López, Los origenes del Consejo de ministros en España. La Junta suprema de Estado, Madrid, Editora Nacional, 2 Vols., 1979. 
momento, el 28 de febrero de 1792 Floridablanca fue destituido como primer ministro bajo acusaciones de corrupción -malversación de fondos en la construcción del Canal Imperial de Aragón- y abuso de autoridad, más si cabe cuando la Junta de Estado se erigió en el símbolo del autoritarismo ministerial en detrimento de la potestad real, por ejemplo, por las continuas prácticas de nepotismo en la provisión de los principales oficios públicos de la Monarquía Hispánica por razones de patronazgo, parentesco, amistad, paisanaje o mera sintonía ideológica. Sin embargo, en buena medida, la drástica providencia fue suscitada por la decisión personal de la apasionada reina María Luisa en favor de las ansias de poder del favorito Manuel Godoy. De cualquier modo, Carlos IV llevó hasta el extremo el absolutismo de su padre, ya que para gobernar no contó con las Cortes ni con el Consejo de Estado. ${ }^{115}$

Los partidarios de la acumulación de todos los poderes en un ministro plenipotenciario, o sea, en definitiva, del despotismo ministerial, defendieron que la propia decadencia del Imperio español, a partir del reinado de los Austrias Menores (finales del siglo XVI y toda la centuria del XVII), hizo necesaria la formación de un ejecutivo que pudiera gobernar de manera autoritaria con el fin de recuperar la magnificencia paulatinamente desvanecida, en palabras del propio conde de Floridablanca: "restituir esta gran monarquía y elevarla a aquel grado de fuerza y esplendor que tuvo en sus tiempos más felices"116. No obstante, precisamente, a partir de la institución de la figura del valido, favorito o privado la decadencia española se fue acentuando hasta llegar al punto de la propia quiebra de la monarquía borbónica en el año 1808 personificada en las renuncias de Bayona y la invasión napoleónica.

De hecho, en relación al modelo gobernativo del conde de Floridablanca, el diputado catalán José Espiga y Gadea se preguntó: "¿Y cuáles fueron los resultados de esta junta [de ministros, llamada de Estado]? ¿Fue desde entonces por ventura más sabio, más justo y expedito el gobierno? ¿Estuvo más protegida la libertad civil del ciudadano?". Para hallar respuestas únicamente era necesario consultar a las personalidades que habian vivido dicho periodo o bien recurrir a los anales de Clio, ya que, de acuerdo al testimonio de la dignidad de la catedral de Lérida "los que conocen la historia de aquel tiempo saben que al entorpecimiento y desorden general se añadió la avocación y resolución de expedientes, que hubieran debido decidirse en los Consejos y tribunales; que entonces empezó la época de los decretos de proscripción, y que no se oyó al

115 La destitución de Floridablanca motivó la inmediata supresión de su Junta de Estado. Véase Cayetano Alcázar Molina, "España en 1792. Floridablanca. Su derrumbamiento del gobierno y sus procesos de responsabilidad politica”, Revista de Estudios Políticos, n 71, 1953, pp. 93-138; Îd., "Ideas politicas de Floridablanca. Del despotismo ilustrado a la revolución francesa y Napoleón (1766-1808)", Revista de Estudios Políticos, no 79, 1955, pp. 35-66; Juan Hernández Franco, La gestión politica y el pensamiento del Conde de Floridablanca, Murcia, Universidad de Murcia, 1984; Îd., "Floridablanca. Entre la reacción y la Revolución (1787-1792)", Estudios románicos, n 6, 1989, pp. 1659-1671; Francisco Andújar Castillo, "El juicio politico a Floridablanca: la creación de la Junta de Estado", Mélanges de la Casa de Velázquez, n 39-2, 2009, pp. 61-81; y Antonio Calvo Maturana, "Floridablanca, Aranda, Godoy y el "Partido de la Reina": La influencia politica de $M^{a}$ Luisa de Parma en los primeros gobiernos de Carlos IV (1788-1796)", Revista de Historia Moderna, $\mathrm{n}^{\circ}$ 28, 2010, pp. 121-146.

116 Juan Hernández Franco, "Pasado y presente de Floridablanca como objeto de la Historia", Mélanges de la Casa de Velázquez, n 39-2, 2009, p. 177. 
Consejo de Estado hasta que la junta se extinguió por otra intriga". ${ }^{117}$ Así que, el pasado reciente no solamente atestiguó la nula separación de poderes entre el ejecutivo, el legislativo y el judicial por la concentración de las tareas gobernativas de forma preferencial en manos de unos primeros ministros que actuaban de manera autocrática, sino que también de un plumazo desvaneció las supuestas capacidades organizativas del régimen absolutista, en buena medida, porque al recurrente desconcierto generalizado cabe adicionar la paralización del aparato administrativo borbónico $\mathrm{y}$, significativamente, el acrecentamiento de una arbitrariedad que diezmaba los ya de por sí escasos derechos y libertades de los súbditos.

De este modo, de manera fehaciente, Espiga y Gadea efectuó una analogía entre la Junta de Estado presidida por Floridablanca y el primer artículo -“los Secretarios del Despacho formarán una Junta"- del segundo capítulo del reglamento interino del Consejo de Regencia. Por dicho motivo, con la finalidad de consolidar el sistema constitucional gaditano, el parlamentario catalán manifestó que "por evitar la arbitrariedad de un Ministro se establece el despotismo pertinente de un cuerpo", preguntándose:

\begin{abstract}
“¿Y será posible que cuando V. M. se ha convocado para derrocar el coloso del despotismo, no se vea que una junta de Ministros es el medio más expedito para volverse a levantar, apoyado sobre una ley? ¿Será posible que en el mismo momento en que V. M. va a poner en ejercicio la Constitución, esta égida de la independencia nacional y de la libertad del español, se haya de dejar en manos de los Ministros una fuerza, de la que abusarán necesariamente para destruir el Consejo de Estado, y el mismo instrumento de que se valieron los Ministros ambiciosos para romper este freno que contenia su arbitrariedad?”. 118
\end{abstract}

La reveladora alocución del eclesiástico Espiga, no olvidemos, integrante de la comisión constitucional, explicitó los principales objetivos del proceso constituyente doceañista: deponer el infausto despotismo, tanto regio como ministerial, para así poder instaurar un nuevo régimen de signo liberal fundamentado en la soberanía nacional, la separación de poderes y la concesión a los nuevos ciudadanos de derechos y libertades propios del liberalismo doctrinario.

De esta forma, los liberales, al vincular independencia con la posibilidad de recobrar la libertad en forma de soberanía y constitución, plantearon la guerra napoleónica como un enfrentamiento contra los despotismos, o sea, contra el tirano exterior Napoleón y contra la tiranía interna de Manuel Godoy ${ }^{119}$, éste último, conocido por su mediocridad y corruptibilidad, el hombre que pasó de los cuarteles a la familia real, ya que su privanza en tiempos de Carlos IV se

117 DSC, núm. 457, 3 de enero de 1812, p. 2541.

118 DSC, núm. 457, 3 de enero de 1812, p. 2541.

119 Antonio Moliner Prada, "En torno al vocabulario politico de 1808”, Anales de la Universidad de Alicante. Historia contemporánea, $\mathrm{n}^{\circ}$ 3-4, 1984-1985, p. 37. En la Consulta al País el magistrado catalán José Solsona sostuvo que "poco importa que esté el Estado libre de enemigos exteriores si abriga en su seno a quien le destruye y aniquila”. ACD, Legajo 6, núm. 29. Valls, 24 de septiembre de 1809. Miguel Artola, Los orígenes de la España contemporánea, op. cit., Vol. II, p. 500. Asimismo, en palabras de Capmany: "fatigado y fastidiado estoy ya de hablar de nuestros enemigos. Napoleones, Franceses, y Godoyones". Antonio de Capmany, Centinela contra franceses. Parte segunda, op. cit., p. 55. 
fundamentó exclusivamente en su amistad con la reina María Luisa. ${ }^{20}$ De infausto recuerdo, en el Congreso gaditano el diputado catalán Antonio de Capmany se refirió a su persona como "Príncipe de la paz (llamado por otros Príncipe de la tinieblas) más fatuo que malo, y más enloquecido que loco, que es aún peor". ${ }^{121}$ Sin duda, la figura de Manuel Godoy ${ }^{122}$ sirvió para explicitar buena parte de las deficiencias del absolutismo borbónico ${ }^{123}$, pero no era la causa del despotismo, sino la consecuencia de un determinado sistema políticoadministrativo que favorecía la arbitrariedad, especialmente en el caso de los nombramientos, ya que se designaban sin necesidad de efectuar ningún tipo de consulta previa al Consejo de Castilla, de hecho, el clientelismo de Godoy ${ }^{124}$ ha estado situado en el pedestal de la "edad del nepotismo" porque hizo del favoritismo su principal arma para gobernar la monarquía, ejerciendo el poder como si se tratase de un rey absoluto, siempre en beneficio de su patrimonio personal y su proyección política. ${ }^{125}$ Dada la experiencia más reciente, no resulta nada extraño que para evitar que el poder ejecutivo abusara de sus facultades Antonio de Capmany se manifestara partidario de limitarlas "por una sabia y vigilante Constitución que le borre hasta los deseos de aspirar a la tiranía". ${ }^{126}$

120 Consultar Emilio La Parra, Manuel Godoy: la aventura del poder, Barcelona, Tusquets, 2005.

121 DSC, núm. 376, 13 de octubre de 1811, p. 2061.

122 En la Consulta al País Antonio de Capmany aseveró que "el disoluto Godoy había corrompido las costumbres con sus escandalosos desafueros". BN, Ms. 20.260/4. Sevilla, 17 de octubre de 1809. Miguel Artola, Los orígenes de la España contemporánea, op. cit., Vol. II, p. 457. En su Centinela contra los franceses Capmany denunció que a su "inexperta y desgraciada mano estaba entregado el timón de esta gran Monarquía, y lo ha estado hasta que él mismo ha echado a fondo la nave y la tripulación (...) negligencia y flaqueza de nuestro Gobierno, depositado con absoluta soberanía en los torpes brazos de aquel disoluto garzón (...) aquel Godoy, instrumento de nuestra ruina". Antonio de Capmany, Centinela contra los franceses, Madrid, Gómez Fuentenebro, 1808, pp. 6 y 10. En la segunda parte añadió: “este malvado, burlándose de la autoridad soberana, y del respetable nombre de la nación; no ha conocido la vergüenza, ni los remordimientos, y ha sobrevivido a sus delitos, amparado de otro más vil y delinqüente que él, y más poderoso [Carlos IV] (...) los millones ya no estaban en España, sino, unos en Francia, y otros en otras partes, adonde habian pasado por varios conductos ocultos (...). Él no nos dejó aquí más que la horrenda memoria de su nombre, y de sus escándalos y estragos (...). Este hombre se había vuelto demente con tanto poder (...). El favorito llevaba ya el cetro, y Carlos solo la corona para tener algo de rey". Antonio de Capmany, Centinela contra franceses. Parte segunda, op. cit., pp. 21-23 y 29.

123 Según el parecer del diputado catalán Felipe Aner era vital restablecer la confianza pública en relación a las operaciones del Tesoro dado que "los Gobiernos que nos precedieron (particularmente los anteriores a nuestra grande insurrección) [Godoy] nos dejaron como en patrimonio el descrédito y la desconfianza”. DSC, núm. 232, 21 de mayo de 1811, p. 1103.

124 Véase Pere Molas Ribalta, "La red Godoy", en Miguel Ángel Melón, Emilio La Parra y Tomás Pérez (edit.), Manuel Godoy y su tiempo, Mérida, Junta de Extremadura, 2003, Vol. I, pp. 361-379.

125 Por ejemplo, Manuel Godoy, en medio año, durante 1791, se hizo ascender de coronel a teniente general mediante tres nombramientos sucesivos, de brigadier, mariscal de campo y teniente general, éste último cuando solamente tenía 24 años, hecho totalmente inédito en la historia militar de la Monarquía Hispánica. Francisco Andújar Castillo, "Nepotismo, clientelismo y fidelidad. De Floridablanca a Godoy (1789-1798)", Cuadernos de Historia Moderna, n VII, 2008, pp. 180-182, 187, 192, 195, 206 y 210-211.

126 DSC, núm. 376, 13 de octubre de 1811, p. 2061. 


\section{IV.- CONSIDERACIONES FINALES}

En su Informe sobre la necesidad en que se hallaba la Monarquía de una Constitución Antonio de Capmany evidenció que para erradicar el absolutismo el proceso constituyente gaditano perfectamente se podía inspirar en la tradición constitucional propia del régimen pactista vigente en la antigua Corona de Aragón porque disponía de una serie de instituciones y mecanismos jurídicos destinados a impedir la despótica soberanía regia. Más si cabe cuando se pretendia evitar la vinculación de la obra doceañista con los innovadores ideales emanados de la Revolución francesa, esencialmente, a raíz de la invasión napoleónica. Por dicho motivo, eso sí, sirviéndose de una mera advocación retórica, Felipe Aner aseveró que las Cortes de Cádiz no representaban una ruptura respecto a la tradición jurídico-política de la Monarquía Hispánica: "No trataremos, Señor, como algunos se han persuadido, de formar una nueva Constitución, o hacer un nuevo pacto social; tratemos, sí, únicamente de restablecer nuestras leyes fundamentales, cuyo olvido ha acarreado a la Nación tantas desgracias". 127 Máxime cuando en opinión de José Espiga era "innegable que nuestros Códigos contienen leyes admirables dictadas por la sabiduria".128 Sin embargo, siguiendo el relato historicista liberal, los antiguos derechos y libertades habian sido cercenados por el ejercicio despótico del poder por parte de los monarcas pertenecientes a las dinastias extranjeras.

En relación a Cataluña, el eclesiástico Espiga y Gadea puso de manifiesto que el despotismo no se originó con la entronización de los Borbones, sino que se inició en tiempos de los Austrias menores, de acuerdo a la progresiva consolidación de los Estados absolutos en la Europa de la Edad Moderna, tal y como se comprobó en el contexto de la Guerra dels Segadors. En concreto, mediante la figura del valido, de hecho, el Conde Duque de Olivares se reveló, tanto en sus actos como en sus escritos, como un precursor de la Nueva Planta de Felipe V. Precisamente, en palabras del historiador Capmany el Principado catalán conservó su modelo constitucional "hasta el año 1714, en que las armas de Felipe V, más poderosos que las leyes, hicieron callar todas las instituciones libres en Cataluña". ${ }^{129}$ Sin duda, los diputados catalanes se valieron del recurso a la historia para hallar la fuente jurídica misma de los derechos para la nación y las libertades para los individuos y, particularmente, como fuente de legitimación

127 DSC, núm. 472, 18 de enero de 1812, p. 2651. De esta manera, la española revolución de nación procuró sustanciarse en la constitucionalización de las leyes fundamentales de la Monarquía, presentando la constitución escrita como reforma liberal de la constitución histórica. De hecho, pese a ser evidente, nunca se planteó la ruptura (tajante y en bloque) del tracto normativo tradicional. Carlos Antonio Garriga Acosta, "Cabeza moderna, cuerpo gótico. La Constitución de Cádiz y el orden jurídico”, Anuario de Historia del Derecho Español, n LXXXI, 2011, pp. 128, 147 y 159.

128 DSC, núm. 132, 5 de febrero de 1811 , p. 500.

129 DSC, núm. 629, 10 de agosto de 1812, p. 3522. El discurso de Capmany nos remite a las palabras del Intendente de Cataluña, el borbónico José Patiño, escritas en su texto particular destinado a elaborar el Decreto de Nueva Planta: "aquel grande orgullo (de los resistentes catalanes) está abatido, y respetan ya los preceptos de Vuestra Majestad, y a la Justicia, no por afecto y amor, sí por la fuerza superior de las armas, de modo que la quietud y obediencia deve afianzarse en éstas, pues la necesita el país por su calidad y genio de sus naturales". Salvador Sanpere i Miquel, Fin de la nación catalana, edición facsimil, Barcelona, Editorial Base, 2000, p. 671 . 
de un proyecto político de signo liberal orientado a impedir, según el criterio del jurista Aner, "la arbitrariedad y el despotismo contra lo que tanto hemos declamado". ${ }^{130}$ En dicho sentido, haciendo uso de la recientemente adquirida libertad de expresión José Espiga denunció el abyecto y represivo absolutismo asegurando que "salimos de un tiempo de esclavitud, en que si había alguna ley fundamental, era solamente conocida por los sabios como un monumento de erudición antigua, y el citarla hubiera sido un crimen de lesa majestad". No obstante, en opinión de la dignidad de la catedral de Lérida, la aplicación de "una Constitución sancionada solemnemente por la Nación y sellada con la sangre de nuestros ilustres defensores, es una barrera impenetrable que no romperá jamás el despotismo". Hasta el punto de vaticinar que "ya no volverán aquellos tiempos en que los Reyes disponían de los derechos de los pueblos como de un patrimonio familiar [por ejemplo, vertiente despótica acrecentada por la deriva patrimonial de una monarquía dirigida por Godoy ${ }^{131}$ ]; porque se borrarán de nuestros Códigos las leyes que inspiraban estas ideas, y recobrarán su vigor las que la arbitrariedad del último Gobierno [reinado de Carlos IV] pretendió que no volvieran a ver los españoles". ${ }^{132}$

De esta forma, la resistencia antinapoleónica comportaba la liberación nacional y, a su vez, la concesión de una constitución que permitiría recuperar las prerrogativas derogadas por el despotismo, ya que, en cierta medida, se estableció una comparación entre la pérdida de la libertad que sufrieron los catalanes en $1716^{133}$ con la perdida por todos los territorios peninsulares durante el año 1808. Especialmente si tenemos presente que el régimen pactista catalán fue capaz de limitar el poder regio, fiscalizar la obra de gobierno, garantizar unos considerables derechos y libertades a los estamentos privilegiados e incluso admitir y promover la participación de los sectores sociales más dinámicos en las Cortes y en el Consejo de Ciento. De hecho, para los diputados catalanes las Cortes de Cádiz perfectamente podían significar la recuperación del constitucionalismo de las últimas Cortes catalanas de 1705-1706. Ciertamente, después de estar sometidos al régimen absolutista durante aproximadamente una centuria, tal y como dilucidó Felipe Aner, el proceso constitucional doceañista permitió fijar "los verdaderos derechos de esta Nación, y las bases de

130 DSC, núm. 472, 18 de enero de 1812, p. 2652.

131 Maria Cruz Romeo Mateo, (2011): “Nuestra antigua legislación constitucional, ¿modelo para los liberales de 1808-1814?”, en Pedro Rújula y Jordi Canal (edit.), Guerra de Ideas. Política y cultura, Madrid, Marcial Pons, 2011, p. 88.

132 DSC, núm. 376, 13 de octubre de 1811, p. 2064.

133 La creación de la Diputación Provincial se consideró heredera de la antigua Diputación del General o Generalidad abolida por Felipe V mediante el Decreto de Nueva Planta. De hecho, cuando la Diputación catalana solicitó a las Cortes de Cádiz la devolución del palacio de la Generalidad de Barcelona recordó que "los primitivos fundadores de la libertad de Cataluña conocieron la necesidad de una Diputación provincial". Precisamente, por el vínculo que se estableció entre la liberal Diputación y la histórica Generalidad se pudieron instalar en la llamada Casa de la Diputación. Carta de la Diputación de 7 de agosto de 1813, reproducida en Josep Sarrión i Gualda, La Diputació provincial de Catalunya sota la Constitució de Cadis (1812-1814 i 1820-1823), Barcelona, Generalitat de Catalunya, 1991, p. 198. Asimismo, véase Maties Ramisa Verdaguer, "La aplicación de la Constitución de Cádiz en Cataluña, 1812-1814", Spagna contemporanea, no 41, 2012, pp. 7-27. 
su libertad politica y civil". ${ }^{134}$ Más si cabe cuando en el Congreso gaditano se fundó el Estado de Derecho, ya que la Constitución de 1812, además de sancionar la soberanía nacional y la separación de poderes, garantizó los derechos individuales sociales y politicos genuinos del liberalismo: libertad política y civil; igualdad; y propiedad.

Finalmente, se ha de destacar que con el objetivo de contener las camarillas cortesanas, las intrigas palaciegas y los manejos ministeriales de los validos, privados y favoritos propios del despotismo gubernamental se procedió a la formación del Consejo de Estado constitucional, todo un referente a la hora de establecer un Estado legal, sellando, de esta manera, la secuencia histórica libertad-despotismo-libertad. Precisamente, merced a dicha disposición José Espiga y Gadea consideró que la carta magna gaditana ofrecía suficientes garantias para que el rey no contase "como hasta aqui con Ministros seductores [por ejemplo, Olivares, Alberoni, Floridablanca o Godoy], que abusando de su bondad, y prevaliéndose de la inviolabilidad real, introducian la arbitrariedad, y hacían servir a los Reyes de instrumento de su despotismo". De este modo, de acuerdo al sentir del parlamentario designado por la Junta Superior del Principado "no es creíble que se repitan los funestos ejemplos de los Gobiernos anteriores". 135 Por el contrario, una vez finalizó la Guerra de la Independencia, el Deseado Fernando VII restituyó el absolutismo mediante la promulgación del famoso Real Decreto de 4 de mayo de 1814, declarando "aquella Constitución y aquellos decretos nulos y de ningún valor ni efecto, (...) como si no hubiesen pasado jamás tales actos y se quitasen de en medio del tiempo". ${ }^{136}$

Enviado el (Submission Date): 03/10/2017

Aceptado el (Acceptance Date): 12/12/2017

134 DSC, núm. 412, 18 de noviembre de 1811, p. 2286.

135 DSC, núm. 369, 6 de octubre de 1811, p. 2001.

136 Real Decreto de Fernando VII derogando la Constitución (Valencia, 4 mayo 1814), Alicante, Biblioteca Virtual Miguel de Cervantes, 2012. Disponible en Http://www.cervantesvirtual.com/md/ark:/59851/bmckd623 